Florida International University

FIU Digital Commons

FIU Electronic Theses and Dissertations

University Graduate School

6-26-2019

\title{
Taking Matters into Your Own Hands: Self-Help and Black Firearm Crime
}

Candice Denise Ammons Blanfort

Florida International University, cammo003@fiu.edu

Follow this and additional works at: https://digitalcommons.fiu.edu/etd

Part of the Criminology Commons

\section{Recommended Citation}

Ammons Blanfort, Candice Denise, "Taking Matters into Your Own Hands: Self-Help and Black Firearm Crime" (2019). FIU Electronic Theses and Dissertations. 4231.

https://digitalcommons.fiu.edu/etd/4231

This work is brought to you for free and open access by the University Graduate School at FIU Digital Commons. It has been accepted for inclusion in FIU Electronic Theses and Dissertations by an authorized administrator of FIU Digital Commons. For more information, please contact dcc@fiu.edu. 


\title{
FLORIDA INTERNATIONAL UNIVERSITY
}

\author{
Miami, Florida
}

\section{TAKING MATTERS INTO YOUR OWN HANDS: SELF-HELP AND BLACK FIREARM CRIME}

\author{
A dissertation submitted in partial fulfillment of \\ the requirements for the degree of \\ DOCTOR OF PHILOSOPHY \\ in \\ INTERNATIONAL CRIME AND JUSTICE \\ by \\ Candice Denise Ammons Blanfort
}


To: Dean John F. Stack, Jr.

Green School of International and Public Affairs

This dissertation, written by Candice Denise Ammons Blanfort, and entitled Taking Matters into Your Own Hands: Self-Help and Black Firearm Crime, having been approved in respect to style and intellectual content, is referred to you for judgment.

We have read this dissertation and recommend that it be approved.

Lisa Stolzenberg

Carleen Vincent-Robinson

Valerie Patterson

Stewart D'Alessio, Major Professor

Date of Defense: June 26, 2019

The dissertation of Candice Denise Ammons Blanfort is approved.

Dean John F. Stack, Jr. Green School of International and Public Affairs

Andrés G. Gil

Vice President for Research and Economic Development and Dean of the University Graduate School

Florida International University, 2019 


\section{ABSTRACT OF THE DISSERTATION}

\section{TAKING MATTERS INTO YOUR OWN HANDS: SELF-HELP \\ AND BLACK FIREARM CRIME}

by

Candice Denise Ammons Blanfort

Florida International University, 2019

Miami, Florida

\section{Professor Stewart D’Alessio, Major Professor}

Black citizens represent $13 \%$ of the U.S. population; however, they account for approximately $53 \%$ of all homicide arrests and $38 \%$ of all arrests for violent crimes. Dejectedly, the high level of violent crime is not only contributing to high Black incarceration rates, but also making disadvantaged neighborhoods worse. Though a number of theories have been advanced to explain the high rate of Black violence, one potential explanation that has received comparatively little attention in the extant literature is the notion of self-help. It is conceptualized as a mode of social control whereby violent behavior is used to punish an individual, express discontentment, and/or achieve restitution.

A significant predictor of the use of self-help as a mechanism of social control is the amount of legal protection provided to citizens by the state. While the police are the primary state agency responsible for providing protection, research consistently shows that Black citizens have a more negative perception of police; hence, it stands to reason that Blacks may be resorting to self-help to increase social control in their communities as opposed to mobilizing law 
enforcement. This could explain why the rate of violent criminal behavior is higher for Black citizens.

Racial population subgroups place considerable value on racial diversity and representation in governmental agencies; thus, it seems reasonable to speculate that having a racially diverse police force would be salient for decreasing self-help among Black citizens by increasing their respect for and belief in the trustworthiness and impartiality of the police. Using a multilevel design and data obtained from the National Incident-Based Reporting System (NIBRS), Law Enforcement Management and Administrative Statistics (LEMAS), and Census for 113 U.S. cities, the current study endeavors to provide a more direct test of whether self-help can explain why violence is higher among Black citizens. Results indicate that the racial diversity of a police force plays a significant role in Black citizens' firearm usage in a crime. Thus, as the racial diversity of a police department increases in a city, the likelihood that a Black citizen will use a firearm in a crime decreases markedly. 


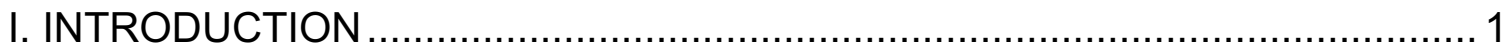

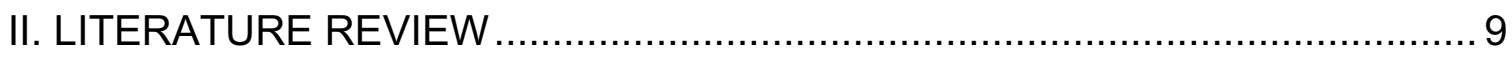

COMMON EXPLANATIONS FOR THE RELATIONSHIP

BETWEEN RACE AND CRIME ........................................................ 9

SELF-HELP AND BLACK CRIME .................................................. 13

PURPOSE OF THE CURRENT STUDY .......................................... 24

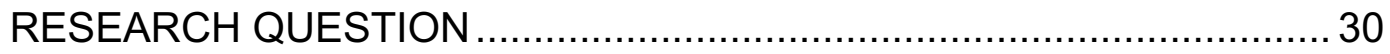

III. METHODOLOGY

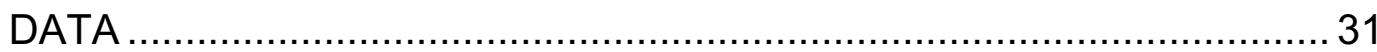

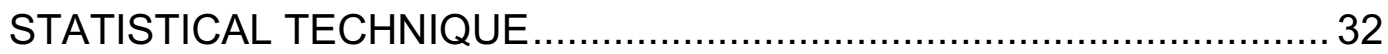

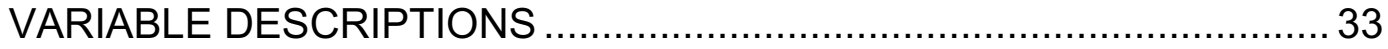

MEASUREMENTS AND CALCULATIONS ….................................... 36

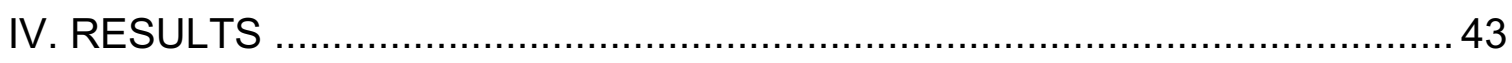

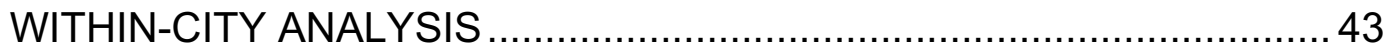

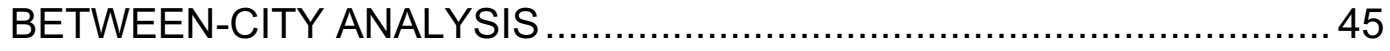

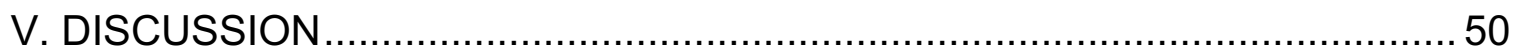

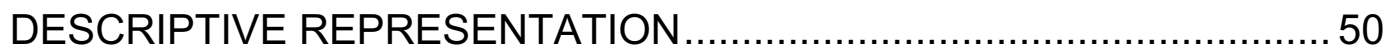

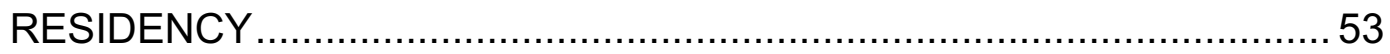

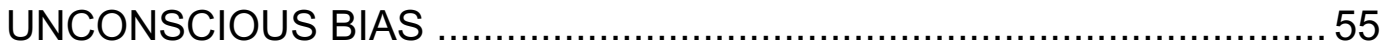

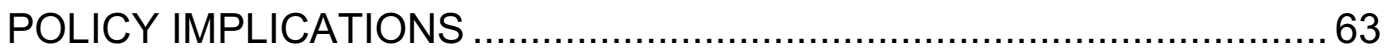

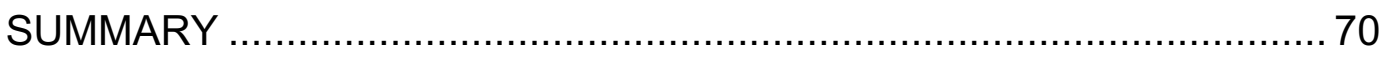

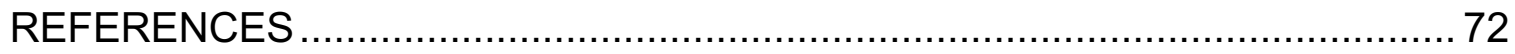

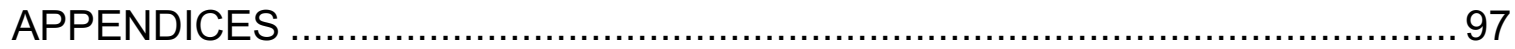

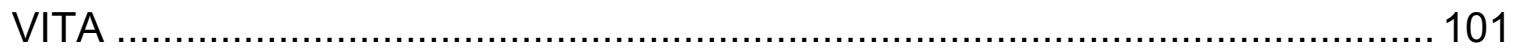




\section{ABBREVIATIONS AND ACRONYMS}

BWC

$\mathrm{FBI}$

ICPSR

LEMAS

NCVS
Body-Worn Camera

Federal Bureau of Investigation

Interuniversity Consortium for Political and Social Science Research

Law Enforcement Management and Administrative Statistics

National Crime Victimization Survey 
LIST OF TABLES

TABLE

PAGE

1. PRINCIPAL COMPONENT ANALYSIS FOR COMMUNITY DISADVANTAGE.

2. MEANS, STANDARD DEVIATIONS, AND DEFINITIONS FOR

VARIALBES USED IN THE ANALYSIS

3. WITHIN-CITY PROBABILTY OF FIREARM USE RESULTS 45

4. BETWEEN-CITY PROBABILTY OF FIREARM USE RESULTS 49 


\section{CHAPTER I \\ INTRODUCTION}

The rates of criminal violence and homicide are remarkably high for Black citizens in the U.S. While representing approximately $13 \%$ of the U.S. population (U.S. Census Bureau, 2017), according to the most recent data, Blacks account for $53 \%$ of all homicide arrests and approximately $38 \%$ of all arrests for violent crimes (Federal Bureau of Investigation, 2018). The high rate of Black violence is by no means a new phenomenon. For more than half a century, the prevalence of violence and murder among Black citizens has remained considerably higher than national averages. It is estimated that $52 \%$ of all homicides recorded between 1990 and 2008 were committed by Black offenders as compared to $45 \%$ by White offenders (Cooper \& Smith, 2017).

Empirical studies that rely on either self-report questionnaires or victimization surveys generally buttress the findings garnered from official data regarding the relationship between race and crime. Despite having some endemic weaknesses (Baumer \& Lauritsen, 2010), self-report and victimization surveys are advantageous in that they can give researchers a more precise snapshot of criminal activity because most criminal offenders are never arrested by police (Cantor \& Lynch, 2000) and because violent crimes involving close acquaintances often go unreported (Jung-Tas \& Marshall, 1999). Studies that depend on self-report data usually find that Blacks admit to committing more crimes than their White counterparts (Cantor \& Lynch, 2000; Freeman, 1996; Lochner \& Moretti, 2004). This differential race effect on the self-reporting of 
criminal activity is enhanced when surveys are distributed in inner-city areas or disadvantaged neighborhoods (Freeman, 1996).

Not only do Blacks admit to committing more crimes than their White counterparts in self-report surveys, but it also seems probable that these data underestimate, to some degree, racial differences in the reporting of criminal activity. Research suggests that the effect of race on the criminal activity reported in self-report surveys is plagued by response bias because of a respondent's hesitancy in reporting socially unacceptable behaviors The underreporting of criminal activity by survey respondents would not be a serious problem if both Blacks and Whites underreported their illegal behaviors at the same rate. However, some research suggests that Black citizens underreport criminal behavior more than their White counterpart. This is perhaps attributed to societal labeling. To further expound, disparaging criminal behavior labels are frequently employed in society to portray Black citizens (Gibbs, 1988), this negative stereotype of Blacks as having an enhanced propensity to partake in illegal activities might induce them to give socially acceptable answers in surveys (Steele, 1997). Studies support this logic by showing that White youth tend to accurately report their criminal involvement while Black youth often minimize their delinquent activities (Hindelang, Hirschi, \& Weiss, 1981; Lab \& Allen, 1984).

Stronger evidence of a differential race reporting effect has also been evinced in studies that compare self-report drug-use data with drug-testing data based on urine samples. D'Alessio, Stolzenberg, and Flexon (2015) found that while Whites and Blacks admit to approximately the same levels of marijuana 
use in interviews conducted in jail following an arrest by police, Black arrestees are still significantly more likely than White arrestees to test positive for marijuana use. Their findings suggest that Black arrestees booked into jails across the U.S. are much more likely than White arrestees to underreport their usage of marijuana.

Victimization surveys also mirror official data regarding the relationship between race and crime. Data drawn from the National Crime Victimization Survey (NCVS), which is a national household survey that gathers information on the characteristics of criminal victimization from individuals aged 12 and older, shows that Blacks are responsible for $32 \%$ of all violent crimes and about $22 \%$ of all nonfatal violent victimizations (Morgan \& Kena, 2017). Some research suggests that Black citizens have an enhanced proclivity to be criminal offenders and are more likely to be victims of violent crime (Black, 1983; Sampson Morenoff, \& Raudenbush, 2005; Whaley, 1992). According to the 2016 NCVS, the rate of violent victimization committed against Blacks (24.1 victimizations per 1,000 persons aged 12 or older) was higher than the rate committed against Whites (20.5 victimizations per 1,000 persons aged 12 or older). The rate of serious violent victimization was also higher for Blacks as compared to those who identified themselves as Asian, Native Hawaiian, or Pacific Islander. Black citizens are especially vulnerable to homicide. The homicide rate for Blacks is approximately 6.3 times higher than for Whites (Smith \& Cooper, 2013). Homicide is the leading cause of death for Black males between the ages of 1834 and the second leading cause of death for males between the ages of 1-4 and 
$10-14$; for females, it is the leading cause of death for those aged 1-4 and 15-24. The stark rates of violence and victimization among Blacks is disturbingly high and has remained relatively stable over the last several decades (Light \& Ulmer, 2016; Smith \& Cooper, 2013).

Although the overall national homicide rate was 4.62 per 100,000 population in 2015, research conducted by the Violence Policy Center (2018) revealed the national Black homicide victimization rate was 18.68 per 100,000 . This study also found that $75 \%$ of all Black victims were killed by someone they knew, while $51 \%$ of Black homicides involved an argument between the victim and offender and $16 \%$ were believed to be gang-related. For all homicides where a weapon could be identified, $86 \%$ of Black victims were killed by a gun. According to a report by the National Center for Health Statistics, an American is 128 times more likely to be killed by firearm violence than by an act of terrorism. More concerningly, the same report estimated that Blacks residing in urban areas were nearly 500 times more likely to be killed by gun violence (Xu, Murphy, Kochanek, \& Bastian, 2016).

Recent research conducted by the Centers for Disease Control and Prevention (2017) concluded that Blacks are eight times more likely than nonBlacks to be killed by a firearm. In a separate report that analyzed the number of gun-related deaths and injuries among U.S. children from 2004 to 2014, researchers found that Black children were nearly 10 times more likely than nonBlack children to die from a gun-related homicide (Fowler, Dahlberg, 
Haileyesus, Gutierrez, \& Bacon, 2017). In fact, the rate of gun-related homicide for children of color is approximately 3.5 per 100,000 population.

Not only is the high level of violent crime and the fear it engenders crippling Black communities, threatening personal freedom, and fraying the ties that are essential for healthy neighborhoods, but it is also contributing to high incarceration rates and making disadvantaged neighborhoods even worse (Light \& Ulmer, 2016). Studies estimate that a Black child born after 2001 is 5.1 times more likely than a White child to be incarcerated (Pettit, 2012). Though the preponderance of academic scholarship focuses on the incarceration of Black males (Gross, 2015), Black females are incarcerated at alarming rates as well. In fact, Black women are three times more likely than non-White Hispanic women to experience incarceration (Ruiz \& Kopak, 2014). Accordingly, 1 in 19 Black women in the U.S. will spend time in prison as compared to 1 in 45 Hispanic women, and 1 in 118 White women. This situation has only been exacerbated by recent crime control efforts (Browning, Miller, \& Spruance, 2018; Gross, 2015).

The high Black incarceration rate in the U.S. has left many Black households with reduced parental supervision in that Black children are nine times more likely than White children to have a parent serving time in prison (Glaze \& Maruschak, 2008). Grandmothers, who are often forced to become the primary caregiver in the absence of the incarcerated mother, frequently lack the resources and skills necessary to effectively rear these parentless children (Smith-Ruiz, 2008; Ruiz \& Kopak, 2014). Children who find themselves in this situation are statistically prone to become delinquent and experience "school- 
related performance problems, depression, and anxiety, low self-esteem, and aggressiveness" (Clear, 2007, p. 97). They are also at an elevated risk of experiencing extreme poverty, limited educational opportunities, racial inequalities, ill physical health and mental health, and higher rates of violence (Dallaire, 2007; Ruiz \& Kopak, 2014; Sameroff, Bartko, Baldwin, Baldwin, \& Seifer, 1998). Black boys separated from their incarcerated parents are nearly five times more likely than White boys in general to experience incarceration as an adult (Murray \& Farrington, 2013). These risk factors tend to be further exacerbated in urban areas already characterized by disenfranchisement (Ruiz \& Kopak, 2014).

Reentry into society after release from prison is problematic as well. Many ex-inmates return home with a host of personal problems acquired during adolescence (such as traumatic memories of sexual and/or physical abuse, alcoholism, depression, addiction, etc.), but these problems are often worsened by imprisonment (Ismalli, 2015). A person stigmatized by a criminal record also finds it burdensome to secure quality and enduring employment because employers often consider people possessing a criminal record as deceitful, lacking germane job skills, and having a penchant for theft (Holzer, Raphael, \& Stoll, 2007; Pager, 2003). Employers also believe that they lessen their exposure to civil liability by not hiring potentially dangerous employees (Beaver, 1997).

Research further suggests that the ability of ex-offenders to find meaningful employment is likely conditioned by an individual's race (Pager, Western, \& Sugie, 2009). The combination of being Black and possessing a criminal record 
acts to amplify both stigma and employment discrimination. Multiple dimensions of a stereotype that are held by a person makes the stereotype more credible and, because of this enhanced credibility, the person is perceived as not deserving a second chance at redemption (Pager, 2007). Not only do studies find that Black job applicants face palpable racial discrimination in the labor market (Bertrand \& Mullainathan, 2004; Pager, 2003), but the effect of an individual's race on employment outcomes becomes even more salient when the individual has a criminal record because of the prevalent stereotype that Blacks, especially young Black males, are dangerous and have a proclivity for partaking in criminal activities (Decker, Ortiz, Spohn, \& Hedberg, 2015; Holzer, Offher, \& Sorensen, 2005; Pager \& Quillian, 2005).

Even if an ex-inmate is fortunate enough to find a job, he or she is likely to encounter diminished wages in the secondary labor market (Western, Kling, \& Weiman, 2001). The secondary labor market is characterized by jobs that have low salaries, high turnover, and scarce opportunities for advancement (Reich, Gordon, \& Edwards, 1973). Such a situation is problematic because low wages act to magnify criminal activity (Freeman, 1996; Gould, Weinberg, \& Mustard, 2002) and criminal recidivism (Needels, 1996). When one considers the strong nexus between unemployment and repeat offending (D'Alessio, Stolzenberg, \& Eitle, 2014), it is not surprising that approximately two-thirds of all ex-inmates are rearrested for a new criminal offense within three years following their release from prison (Cook, Kang, Braga, Ludwig, \& O’Brien, 2015; Johnson \& Cullen, 2015; Fine et al., 2018). Moreover, the high recidivism rate worsens living 
conditions and crime rates in neighborhoods already plagued by crime and violence because ex-inmates, especially Black ex-inmates, have a tendency to return to their old neighborhoods following their release from prison (Massoglia, Firebaugh, \& Warner, 2013). 


\section{CHAPTER II}

\section{LITERATURE REVIEW}

\section{COMMON EXPLANATIONS FOR THE RELATIONSHIP BETWEEN RACE}

AND CRIME

With such a multitude of documented adverse consequences emanating from criminal violence, criminal victimization, and incarceration, social scientists have endeavored to identify the social factors responsible for the observed racial difference in criminal behavior. Several competing theories have been advanced in the literature. Conflict type explanations that emphasize racial inequalities in society are among the most prominent. The unequal distribution of wealth is often cited to help explicate the high Black crime rate (Allen \& Steffensmeier, 1989; Byrne \& Sampson, 1986; Kelly, 2000; Shihadeh \& Steffensmeier, 1994). Although economic inequality is thought to contribute to a high crime rate in general, it is theorized to have an enhanced effect on Black crime levels (Sampson, Wilson, \& Katz, 2018). The premise for this belief is rooted in Merton's (1957) theory of anomie. While Durkheim (1897) focused on how rapid changes in society contributed to the breakdown of cultural norms, Merton (1957) sought to ascertain why rates of deviance varied across diverse societies and different subcultures within the same society. He attributed crime rate differentials within the same society to the inability of some individuals to attain society's definition of success using culturally appropriate ways to actualize established goals. Anomie, or the breakdown of cultural norms, occurs when there is an absence of legitimate means to obtain an established goal. 
Merton (1959) argued that people within society react differently to their inability to achieve prescribed goals. He offered a typology of adaptions including conformity, innovation, ritualism, retreatism, and rebellion. Of particular interest and relevance for crime is the concept of innovation. Merton claimed that some people may find alternative and often illegal ways to obtain society's definition of success because their access to legitimate means for achieving such success is severely limited. While Merton's theory was developed pre-civil rights, many sociologists and criminologists note that individuals of color still face unequal access to employment, education, and opportunities for advancement (Hamilton, Darity, Price, Sridharan, \& Tippett, 2015; Harper, 2008; Harper, Patton, \& Wooden, 2009; Kalev, 2009). Moreover, economists still observe an apparent income and economic inequality gap among Blacks and other minorities as compared to their White counterparts (Buonanno \& Vargas, 2017).

Several empirical studies have sought to determine whether economic inequality contributes to criminal violence. The results generated in these studies are mixed. While racial income inequality has been shown to have a direct effect (Blau \& Golden, 1986; Blau \& Schwartz, 1984) or indirect effect (Blau \& Blau, 1982; Shihadeh \& Steffensmeier, 1992) on Black violent crime levels, other researchers evince only partial evidence (Blackwell, 1990; Messner \& Golden, 1992; Williams, 1984) or no evidence at all (Blackwell, 1983, Carroll \& Jackson, 1983; Patterson, 1991; Harer \& Steffensmeier, 1992; Light \& Ulmer, 2016) for either type of relationship. 
Many economists also attribute criminal involvement to a weak labor market (Nordin \& Almen, 2016). The origins of economic theories related to crime are generally found in the late-eighteenth-century work of Cesar Beccaria and Jeremy Bentham, who asserted that humans are rational actors driven by selfinterest. Building on Beccaria and Bentham, Becker (1974) argued that an individual's decision to criminally offend was based on the availability of legal opportunities, the cost and expected value of legitimate behavior versus the availability of illegal opportunities, and the cost and expected utility of partaking in illegal behavior. Micro-level research consistently finds that individuals participating in the labor force are less likely to become involved in crime and violence (Danziger, 1976; DuRant, Cadenhead, Pendergrast, Slavens, \& Linder, 1994; Duster, 1987). This nexus between labor market status and criminal activity has also been shown to be especially applicable to Black males (Viscusi, 1986). This is significant because Blacks tend to reside in communities with extremely high rates of unemployment (Light \& Ulmer, 2016).

Social disorganization theory is also commonly advanced to explain high crime and violence levels in the Black community. This theory argues that crime in urban areas is driven by high rates of poverty, heterogeneity, and instability. These factors weaken informal mechanisms of social control which, in turn, increase the probability of criminality while simultaneously reducing community trust. Informal controls are necessary to promote societal norms and to ensure behavioral conformity in the community (Felson \& Cohen, 1980). 
Finally, the familial structures of Black and White families differ markedly. The number of single-female-headed households within the Black community increased by more than $100 \%$ from 1960 to 1980 (Wilson \& Aponte, 1985). Since then, the number of one-parent Black households has continued to rise. Using data drawn from the most recent census, the Pew Research Center (2015) found that $38 \%$ of all Black children under the age of 18 live with both parents, as compared to $73 \%$ of all White children. Most of these single-parent households are headed by women. Almost one-third of Blacks live with a single mother, while less than $7 \%$ of Whites have families with a single female heading the household. These statistics represent a particular challenge in light of the oftenreported correlation between familial structure and crime.

Single-family households are problematic in that they tend to be more unstable than two-parent households. Research consistently shows that households void of structure and stability are more vulnerable to a variety of negative outcomes such as juvenile delinquency (Anderson, 2002), sleep problems (Troxel, Lee, Hall, \& Mathews, 2014), and a lack of participation in community activities and voluntary organizations (Sampson, 1987). Research also suggests that one-parent households are less likely to exercise informal social control in the community (i.e. questioning strangers, watching a neighbor's property, and supervising youth activities), because they may lack the resources or autonomy needed to provide supervision and/or support (Felson \& Cohen, 1980). For this reason, Black youth are often left without adult supervision. Several empirical studies also highlight the adverse effects that family disruption 
has on crime and violence in Black communities. For example, Sampson (1987) found that Black violent offending was strongly affected by family structure variation. Similar findings were produced by Lafree, Baumer, and O'Brien (2010). They found that cities with a greater gap between Black to White children singleparent family rates had higher levels of Black homicide and violence.

\section{SELF-HELP AND BLACK CRIME}

One potential explanation for the high rate of Black crime and violence that has received comparatively little attention in the extant literature is the notion of self-help. The underpinnings of self-help theory are rooted in social contract theory (Hobbes, 1651). Fundamentally, state- and government-imposed criminal sanctions were originally designed to protect citizens. Hobbes advanced the argument that an absolutely free state would inevitably produce chaos and constant war. In such a bleak situation, citizens could only ensure themselves a peaceful existence by transferring their freedom to the state in exchange for the state's protection (Garland, 2012). The government, in this interpretation, is the only viable entity capable of delivering security for the people and freeing them from conflict. Hobbes (1651, p. 63) argued that, without citizens' submission of their personal freedoms to the state for protection, there would be "no arts, no letters, no society, and, which is worst of all, continual fear and danger of violent death, and the life of man solitary, poor, nasty, brutish, and short."

In his seminal work, Donald Black (1983) elaborated on social contract theory. He conceptualized self-help as a mode of conflict management with crime and violence acting as practicable devices of informal social control. For 
example, studies of indigenous tribes found that violent forms of self-help such as murder, maiming, and beating were not outlawed, but were used as means of informal social control (Barton, 1969; Bohannan, 1960; Hoebel, 1954; Langness, 1972; Nash, 1967). Self-help in these primitive societies also encompassed shared liability, whereby persons from a particular social category were held responsible for the misconduct of their peers. Thus, in primitive settings, violence often emanated from a perceived grievance against a person or group.

Self-help in modern society closely resembles the modes of conflict management and social control found by many anthropologists in primitive societies because violent behavior is still intended to punish an individual or individuals, express discontentment, and/or achieve restitution (Black, 1973, 1983). Purveyors of self-help view their grievances as their own business, not that of the state or other public officials, and they resent the intrusion of formal law into their personal lives (Black, 1983). They also believe that their actions, however violent, are morally justified. Black (1983, p. 34) writes that, "far from being an intentional violation of a prohibition, much crime is moralistic and involves the pursuit of justice." A person motivated by self-help often does not view his or her action as a law infraction, express remorse, or feel guilty. These individuals, instead, typically feel empowered, proud of their conduct, and revel in the actualization of "self-administered" justice. Black (1983) further asserts that a significant predictor of the occurrence of self-help in modern society is the amount of legal protection provided by the state. Research supports this view in that citizens are reported to have an enhanced proclivity to take the law into their 
own hands when they feel that the state is unwilling or incapable of furnishing them with adequate protection (Black and Baumgartner, 1987; Haas, de Keijser, \& Bruinsma, 2014; Jackson, Huq, Bradford, \& Tyler, 2013; Reiss \& Bordua, 1967; Tankebe, 2009; Wilkinson, Beaty, \& Lurry, 2009).

While there are a multiplicity of criminal justice agencies that represent the interests of the state in modern society, the police are typically considered the most visible to the public and the first point of contact for entry into the criminal justice system. Consequently, public perception of the state's ability to establish order and afford protection is related to public satisfaction with the police. Curiously, satisfaction with the police has been found to vary by the race of the individual. White and Black citizens view the police differently, with Blacks more likely than Whites to hold unfavorable attitudes toward the police. Because research shows that Blacks have a more negative perception of police than Whites and because the police are the primary state agency responsible for providing citizens with protection, it stands to reason that Blacks may be resorting to self-help to increase social control in their communities. This situation, in turn, may explain why the rate of criminal behavior, especially violent criminal behavior, is higher for Black than for White citizens in our society.

There is an exceptionally large racial gap in attitudes toward police. Surveys have repeatedly shown that Black citizens distrust the police more than Whites (Avakame, Fyfe, \& McCoy, 1999). In fact, Whites typically have more confidence in law enforcement than all other minorities (Garofolo, 1977; Hindelang, 1974; Huang \& Vaughn, 1996; Tyler, 2005). A recent survey conducted by Pew 
Research Center in 2016 revealed that Blacks were only half as likely as Whites to have a positive view of local police (Morin \& Stepler, 2016). Only 33\% of Black respondents reported that the police patrolling their neighborhood "do a good job," as compared to nearly $75 \%$ of Whites. Additionally, while $78 \%$ of Whites expressed feeling safe from crime, only $48 \%$ of Blacks believed that the police were doing a decent job in protecting them from crime. Cobbina, OwusuBempah, \& Bender, (2016) interviewed Black protesters in Ferguson, Missouri after an unarmed Black man, Michael Brown, was shot and killed by a White police officer, Darren Wilson. Their analysis revealed that $31 \%$ of the Black protestors interviewed felt that the police typically viewed Black citizens as being criminally disposed and Whites as being noncriminal.

Many Black adolescents and teenagers also have an unfavorable view of law enforcement (Brunson, 2007; Brunson \& Miller, 2006; Hurst, Frank, \& Browning, 2000; Stewart, Baumer, Brunson, \& Simons, 2009; Taylor, Turner, Esbensen, \& Winfree, 2001). Black youth's negative perception of law enforcement is largely attributed to combative police encounters and to vicarious experiences shared by elders or friends within the community. Analyzing data obtained from high school students in Cincinnati, Hurst et al. (2000) found that only $44 \%$ of Black teenagers believed that the police would help those in need of assistance as compared to $58 \%$ of White respondents. Additionally, while only $32 \%$ of Blacks reported that the police effectively maintain order, nearly $50 \%$ of White students evaluated police performance in a positive light. Using data drawn from the National Evaluation of the Gang Resistance Education and Training program, Taylor et al. 
(2001) observed that Black teens held the least favorable perception of law enforcement, as compared to Whites, Asians, Hispanics, and Native Americans.

In addition to expressing considerable dissatisfaction with police, Blacks are also more likely than Whites to report feelings of injustice (Decker, 1981;

Flanagan \& Vaughn, 1996; MacDonald \& Stokes; 2006), to perceive that they have been victims of racial profiling (MacDonald, Stokes, Ridgeway, \& Riley, 2007; Lundman \& Kaufman, 2003), and to be the targets of excessive use of police force (Flanagan \& Vaughn, 1996). These negative feelings also tend to be amplified in Black neighborhoods characterized by social and economic disadvantage (Weitzer, 2002). While the perception of police has been shown to vary by the socioeconomic status of the individual (MacDonald et al., 2007), Weitzer and Tuch (1999) report that Blacks with higher educational attainment are more likely than Blacks with less education to perceive police as being racially biased. Ostrom and Whitaker (1974) also observed that Blacks of higher economic status held more negative attitudes toward law enforcement than lower-income Blacks. The long-standing history of police brutality (Kennedy, 1997; Walker, 1998) and recent shootings of unarmed, non-violent Blacks have only exacerbated mistrust and negative views of the police in Black communities across the U.S. (Futterman, Hunt, \& Kalven, 2017).

Fagan and Tyler (2005) point out that people develop a framework for interactions with police based on a very limited number of experiences with law enforcement. In addition to drawing on personal experiences, Blacks also make assessments based on events that they are exposed to in their communities 
(Weitzer, 2002) and to the information disseminated by their family and friends (Feagin \& Sikes, 1994). More specifically, Feagin and Sikes (1994, p. 16) assert that "a Black victim frequently shares the account with family and friends, often to lighten the burden, and this sharing creates a domino effect of anguish and anger rippling across an extended group." As such, indirect contacts with police are commonly referred to as "vicarious" experiences. Rosenbaum, Schuck, Costello, Hawkins, and Ring (2005) found that the effects of negative vicarious experiences were greatest among Black citizens, as compared to Whites and Hispanics. These secondhand experiences are often detrimental to police efficacy, law legitimacy, and to the perception of law enforcement generally. Consequently, Blacks are more prone to be hostile in their interactions with police officers (Browning, Cullen, Cao, \& Kopache, 1994) and less likely to provide aid needed to assist police in solving crimes (Futterman, et al., 2017; Gibson, Walker, Jennings, \& Miller, 2010).

Studies find that, in addition to being less trusting of police than Whites (Barlow \& Barlow, 2002; Hagan \& Albonetti, 1982; Sampson \& Bartusch, 1998; Webb \& Marshall, 1995; Weisburd, Greenspan, Hamilton, Williams, \& Bryan, 2000; Weitzer, 2000a; 2000b; 2002; Weitzer \& Tuch, 2002), Black citizens are also less tolerant than Whites of violence occurring in their neighborhoods (Sampson \& Bartusch, 1998). Community-oriented and problem-solving policing have been implemented in many urban areas to increase citizen confidence in the police and to improve the willingness of residents to participate in anticrime initiatives (Cao, Frank, \& Cullen, 1996; Gill, Weisburd, Telep, Vitter, and Bennett, 
2014; Goldstein, 1987; Kelling, 1988). Citizen support and cooperation with law enforcement is thought to increase efficacy which, in turn, benefits the community by lowering crime rates (Gibson et al., 2010; Tyler, 2005). However, these types of community initiatives are only effective when citizens have confidence in the police (Gibson et al., 2010; Tyler, 2005). Recent research suggests that negative citizen perceptions of police are compromising the success of these types of programs (Futterman et al., 2017; Gibson et al., 2010). For example, in an assessment of the effect of traffic stop encounters on subsequent calls to the police for service, Gibson et al. (2010) found that nonHispanic Black men were significantly less likely to report neighborhood problems or to call the police after contact with law enforcement as compared to non-Hispanic White men. This situation is particularly troubling for cities and for the poor because the likelihood of crime victimization is usually higher in urban areas (Vacha \& McLaughlin, 2004; Watkins \& Melde, 2018) and because those residing in more economically disadvantaged neighborhoods experience higher rates of violent crime and personal theft (Galster \& Santiago, 2015; Karmen, 1990; Paterson, Krivo, \& Harris, 2000; Ringel, 1996; Smith \& Jarjoura, 1989; Vacha \& McLaughlin, 2004). Thus, Black citizens' distrust of the police can have a knock-on effect for urban areas and the poor.

The police also typically rely on the citizenry to help them solve crimes (Moore, 1992; Gibson et al., 2010; Grabosky, 1992; Reisig \& Lloyd, 2009). Because physical evidence is rare at most crime scenes, the police must rely on two simple methods to link an individual to a specific crime. A police officer can 
personally observe the criminal offense or crime victim(s) or witness(es) can testify against the alleged offender(s). In most cases, however, the police arrive too late to see the criminal offense being committed. Accordingly, the police are usually forced to rely on the testimony of the victim(s) and/or witnesses to obtain the required evidence to effectuate an arrest. However, Blacks are much less likely than Whites to cooperate with the police because they often perceive the police as being biased against them (Peffley \& Hurwitz, 2010).

The unwillingness of many Black citizens to assist law enforcement ultimately lowers the likelihood of arrest, which can increase crime by reducing the certainty of punishment. Despite conventional wisdom, research suggests that Black citizens are under-policed rather than over-policed, at least for violent offenses. Using data from the National Incident-Based Reporting System, D'Alessio and Stolzenberg (2003) assessed the effect of an offender's race on the probability of arrest for the crimes of forcible rape, robbery, aggravated assault, and simple assault. These four crimes were analyzed because it is in these types of offenses that the victim is confronted by the criminal offender and can get some indication of the offender's race and other demographic characteristics. The baseline model for their comparisons was the equiprobability hypothesis that, relative to violation frequency as reported by crime victims, the likelihood of arrest for White and Black offenders would be roughly equal. Their multivariate logistic regression results showed that the odds of arrest for White offenders were approximately $22 \%$ higher for robbery, $13 \%$ higher for aggravated assault, and $9 \%$ higher for simple assault than they were for Black offenders. The race of the offender 
played no noteworthy role in the likelihood of arrest for the crime of forcible rape. This study showed that, relative to violation frequency as reported by crime victims, the probability of arrest for Black offenders was substantially lower than for White offenders.

When one considers that most crime is intraracial rather than interracial, a strong argument can be advanced that Black citizens are not being afforded the same level of police protection typically afforded White citizens. Thus, if the state is less apt to respond effectively to the crime-control needs of Black citizens, this suggests that many Black citizens may feel obliged to rely on themselves for protection and for achieving justice when they perceive that they have been wronged in some way.

When people regard the state as untrustworthy and unable to provide protection, they are more likely to take precautionary measures such as owning a gun to provide protection and handle disputes (Jackson et al., 2013; Smith \& Euchida, 1988; Tankebe, 2009). Several studies have found that people purchase firearms for self-protection (McDowall \& Loftin, 1983), particularly Black citizens (Gau \& Bronson, 2015; Kleck \& Getz, 1998; Lizotte, Bordua, \& White, 1981). Smith and Uchida (1988) examined the effect of household and neighborhood context on firearm ownership for self-protection. Specifically, they assessed the influence of crime rates, racial composition, prior victimization experience, and perceptions of police on the decision to purchase a gun in 59 residential neighborhoods in Rochester (New York), Tampa-St. Petersburg (Florida), and St. Louis (Missouri). Results showed that nonWhite households 
and those households that experienced past victimization were more likely to purchase a weapon. They also found that the percentage of households who reported obtaining a weapon was significantly higher among those who rated the police as "very poor" or "inadequate."

Not only are citizens more inclined to purchase firearms for protection when they believe the state is unable to protect them, but research consistently reveals that citizens are more inclined to rely on self-help when they believe that the state is not protecting them (Haas et al., 2014; Jackson et al., 2013; Reiss \& Bordua, 1967; Tankebe, 2009; Wilkinson et al.,2009). Tankebe (2009) assessed whether public support of violent self-help tactics such as vigilantism was influenced by citizens' perceptions of procedural justice in Ghana. A multistage sampling technique was utilized to randomly select 450 households from the Census Enumeration Areas in Accra, Ghana. He found that police trustworthiness was the strongest predictor of vigilantism. Ghanaians who perceived the police to be less trustworthy were more likely to support the use of vigilante violence.

Similarly, Haas et al. (2014) provided participants with a vignette (which described a hypothetical criminal act and subsequent acts of vigilantism to measure confidence in police and public support for vigilantism. They found that police responsiveness and confidence in the police both influenced support for vigilantism. As confidence in the police increased and the police responded more promptly to a reported crime, public support for vigilante justice decreased. Jackson et al. (2013) assessed police legitimacy and public attitudes towards the 
use of violence for self-protection to help ensure social control. Using data obtained from minority males between the ages of 13 and 30 from London Boroughs in the United Kingdom, Jackson et al. (2013) analyzed the correlation between police legitimacy and attitudes toward private violence. Consistent with previous scholarship, the results revealed that procedural justice was significantly correlated with pro-violent attitudes among minority males. Respondents who viewed law enforcement as untrustworthy were also more likely to support the use of violence for self-protection.

Qualitative studies also consistently find that citizens are more inclined to rely on self-help by taking the law into their own hands when they believe that the state has abdicated its role in furnishing protection for its citizenry. Brunson and Gau (2015) analyzed the relationship between perceived procedural injustice, eroded police legitimacy, and reliance on self-help in urban minority areas with high crime rates. Data were obtained from in-depth interviews of young men in three distinct St. Louis neighborhoods. These neighborhoods included a majorityWhite neighborhood with low crime, a mixed-race neighborhood with little crime, and a majority-Black neighborhood with high rates of violent crime. Brunson and Gau (2015) found that respondents living in the majority-Black neighborhood with the high rates of violent crime frequently reported feeling safe in their neighborhoods because of collective violence instead of police presence. One respondent summed up this view as follows: "if anybody try to like jump me or whatever, my brothers and my friends have my back" (Brunson and Gau, 2015, p. 143). Youth also identified police as being potentially dangerous and as 
contributing to fear in the community. Police presence in the high-crime urban area heightened respondents' anxiety and perceived threat to "both physical safety and overall well-being" (Brunson and Gau, 2015, p. 144).

Wilkinson, et al., (2009) analyzed data on 416 active violent offenders drawn from the New York City Youth Violence Study and found that more than $60 \%$ of the Black youth surveyed regarded the police as ineffective in reducing neighborhood violence. One respondent asserted: "Youth cannot trust the police to protect them" and "if we could trust them [the police] to protect us [citizens] would not need guns for self-protection" (Wilkinson, 2009, p. 33). Youth also viewed police as corrupt and felt that the presence of police in their neighborhood exacerbated conflict because the police often viewed them as criminals. Furthermore, many of the youth involved in the study felt justified in their actions and involvement in crime. They were simply using violence as a means of protection and of vengeance following a criminal victimization.

\section{PURPOSE OF THE CURRENT STUDY}

Although informative, prior studies have only shown limited support for selfhelp because they measure self-help using either gun ownership for selfprotection (Kleck \& Getz, 1998; Lizotte et al., 1981; McDowall \& Loftin, 1983; Smith \& Uchida, 1988) or pro-violent attitudes in people lacking confidence in the police (Hass et al., 2014; Jackson et al., 2013; Tankebe, 2009). It is important to recognize that, just because firearms are acquired for self-protection, this does not necessarily mean that these firearms are being used by their owners to commit crimes in the community. The same logic applies to the manifestation of 
pro-violence attitudes in people lacking confidence in the police. Attitudes are not behaviors; a person can have pro-violence attitudes but not act upon them (Schuman \& Johnson, 1976). Thus, prior studies on self-help have difficulty in determining, with any degree of empirical certainty, whether self-help is contributing to the higher rates of criminal violence among Black citizens.

The current study endeavors to provide a more direct test of whether selfhelp can explain why violence tends to be higher among Black citizens by analyzing city offense data drawn from the National Incident-Based Reporting System (NIBRS). The use of NIBRS to test the validity of self-help is advantageous for several reasons. First, it allows for the creation of a broad and theoretically relevant measure of self-help: crimes committed with a firearm. This measure, which has not been used previously by researchers, is theoretically important because it is a behavioral rather than an attitudinal measure of selfhelp. While previous studies buttressing the logic associated with self-help have found that individuals are more likely to obtain firearms for self-protection when they lack confidence in the police (Gau \& Bronson, 2015; Kleck \& Getz, 1998; Lizotte et al., 1981), the question of salience for the theoretical adequacy of selfhelp theory as a potential explanation for violent crime is whether the lack of confidence in the police is actually engendering firearm violence rather than simply increasing individuals' ownership of firearms for self-protection. The findings generated in most prior studies that empirically supported self-help theory can thus be questioned to some degree because they failed to establish a 
clear nexus between confidence in the police and any violence resulting from the use of self-help.

A second benefit of NIBRS in testing self-help is that firearm crime data can be disaggregated by the demographic characteristics of the offender. For example, a researcher can determine whether a Black offender used a firearm when committing a crime. The ability to distinguish Black from White offenders is important because Blacks may be more apt than Whites to rely on self-help because they typically have less confidence in the police. Victim data are also included in the NIBRS. For example, the relationship between the criminal offender and the crime victim can be identified in the NIBRS. The ability to control for the relational distance between the offender and victim in a firearm crime is helpful in testing self-help theory because self-help crimes are theorized to be more common among individuals of close relational proximity (Black, 1983).

Finally, NIBRS data are useful in that the data set contains geocode information that identifies the city where each crime incident occurred. These geographic identifiers can be employed to match firearm crimes committed by a Black offender with a confidence in the police aggregate measure (police department racial diversity) and with other city-level variables drawn from the census that are theorized to be predictive of general firearm crimes.

The present study uses the racial diversity of a city's police department (percentage of Black police officers) as a proxy measure of Black citizens' confidence in the police. Since racial population subgroups in society place considerable value on racial diversity and on representation in governmental 
agencies because they believe it ensures racial equality (Barrett, 1995, 1997; Gay, 2001; Haider-Markel, Joslyn \& Kniss, 2000), it seems reasonable to speculate that having a racially diverse police force would be salient for decreasing self-help among Black citizens by increasing their respect for and belief in the trustworthiness and impartiality of the police. These factors are considered crucial for the establishment of police legitimacy (Tyler, 1997).

A large body of research tends to support this position by showing that an increase in the number of Black law enforcement officers in an area improves Black citizens' trust in police and enhances perceptions of police effectiveness (Brunson \& Gau, 2015; Skogan, 1979; Weitzer, 2000a, 2015). For example, using data derived from the Police-Public Contact Survey, Theobald and HaiderMarkel (2009) found that Black citizens were much more likely to perceive police stops as legitimate if a Black officer rather than a White police officer initiated the police-citizen interaction. Black respondents were also more apt to report that the police officer acted properly during the interaction when the officer was Black. In a similar study, Hong (2017) analyzed longitudinal data from the Police Compliance and Discipline Report and the Police Complaints Commission in the United Kingdom. Results revealed that as the proportion of ethnic minority officers increased for a given year, the number of complaints brought by minorities decreased the following year. Additionally, Hong noted that increased minority representation reduced misconduct and improved organizational integrity. In an earlier study, Hong (2015) showed that a rise in the number of ethnic minority police officers was correlated with a decrease of reported crime 
incidents in London and Wales. In fact, a mere 10\% increase in the number of ethnic minority police officers resulted in a $1.4 \%$ to $3.8 \%$ reduction in crime for the analyzed years.

Studies have also found that Black citizens are more reticent about seeking assistance from police when they believe that police officers are ill-equipped and/or unable to identify with the values of the Black community (Futterman et al., 2017). Research consistently reveals that a large number of criminal offenses go unreported in poor neighborhoods of color because Blacks often have cynical views of the criminal justice system (Kirk \& Matsuda, 2011). Citizens may believe that reporting a crime or contacting the police is futile because nothing will be done to resolve the crime or apprehend the perpetrator. Additionally, and apparently paradoxically, areas with the highest crime rates frequently have the lowest arrest rates. This crime-arrest disparity is largely attributed to the prevalence of legal cynicism in minority communities. Perceived or known neglect by the police, as well as misconduct and harassment, produce legal cynicism among the population (Terrill \& Reisig, 2003), which, in turn, amplifies violence and lawlessness in communities of color as citizens in these communities are less likely to mobilize law enforcement (Kirk \& Papachristos, 2011). A large number of Black police officers working in the Black community has the potential to attenuate crime because of shared norms and cultures between the police and the community that they patrol (Gay, 2001; Theobald \& Haider-Markel, 2008). It is also likely that increased minority representation in a police department influences departmental culture (Legewie \& Fagan, 2016), 
which can reduce crime by affecting citizens' overall perception of police legitimacy.

Not only are citizens' perceptions of law enforcement and legal cynicism integral to crime control, but formal and informal mechanisms of social control are less effective when citizens view the law as illegitimate and/or hold cynical views towards the justice system (Carr, 2003; Lee, Steinberg, Piquero, \& Knight, 2011). This situation arises because effective informal social control entails strong law enforcement and citizenry alliances that can act in concert to attenuate crime (Carr, Napolitano, \& Keating, 2007). Along these lines, research finds that police responsiveness is linked to citizens' perceptions of law legitimacy (Klinger, 1997; Moskos, 2008; Smith, 1987). Police who believe citizens to be cynical are less likely to assist and may even respond more slowly in providing the required assistance (Reisig \& Giacomazzi, 1998). Such a situation has the potential to result in a cyclical pattern of cynicism, for both police and citizens alike.

In sum, there are a multitude of adverse consequences associated with a negative perception of law enforcement. Policies to improve law legitimacy in Black communities not only have the potential to significantly attenuate lawlessness and violence because people with more favorable views of law enforcement are more likely to contact police as opposed to personally resolving a dispute (Moskos, 2008), but they also can increase arrest rates because residents who perceive the police as responsive and supportive are more willing 
to intervene to prevent a crime and to risk their personal safety by assisting police with the apprehension of criminal suspects (Kirk \& Matsuda, 2011).

\section{RESEARCH QUESTION}

Guided by the theoretical rationale discussed above, this study broadens the scope of previous inquiry on the theory of self-help by using a multilevel model to analyze data drawn from the NIBRS and the census to test the following:

Are Black offenders less likely to use a firearm during the commission of a crime in cities with a racially diverse police force? 


\section{CHAPTER III \\ METHODOLOGY}

Individual-level data on crime incidents were obtained from the FBI's NIBRS (Federal Bureau of Investigation, 2015). The NIBRS was implemented "to enhance the quantity, quality, and timeliness of crime statistical data collected by the law enforcement community and to improve the methodology used for compiling, analyzing, auditing, and publishing the collected crime data" (Federal Bureau of Investigation, 2000, p. 1). The Blueprint for the Future of the Uniform Crime Reporting Program highlights the guidelines and the specifications used in the development of NIBRS (Abt Associates, 1985). The NIBRS is advantageous for researchers studying crime because it can produce more detailed, accurate, and meaningful data than that generated by the traditional Uniform Crime Reports.

\section{DATA}

The NIBRS data used in the present study was obtained from incidents reported in 2015 and represents 150,365 offenders in 113 cities (in 37 states), each with a minimum population of 50,000 . These data are archived at the Interuniversity Consortium for Political and Social Science Research (ICPSR). The overall sample size includes only violent incidents involving a single offender and single victim. It was necessary to exclude crime incidents in which there were multiple offenders from the analysis. In such multiple-offender cases, it is extremely difficult to estimate the probability of firearm use among Black offenders because there could be Black and White offenders in the same co- 
offending crime incident. Violent crimes including more than one victim were also excluded from the analysis because of the difficulty in controlling for demographic characteristics of multiple victims in the analysis. The NIBRS data set provides information on individual-level factors associated with firearm use such as the sex, age, and race of offenders and crime victims as well as weapon usage, relationship between victim and offender, and offender's drug use. The data set also has geocode information that identifies the city where the reported crime incident occurred. These geographic identifiers can be used to match crime incident data with law enforcement data and census taken to be predictive of firearm use.

\section{STATISTICAL TECHNIQUE}

Since the data are multilevel and the dependent variable is a dichotomous, this study employs a nonlinear hierarchical modeling methodology (Bryk, Raudenbush, \& Congdon, 1996). This statistical technique employs a penalized quasi-likelihood $(\mathrm{PQL})$ procedure to generate parameter estimates for a binary outcome (Breslow \& Clayton, 1993). There are several methodological advantages for using a multilevel model to test the self-help thesis. First, multilevel models like the one used here avoid violating the assumption of independence among observations because they explicitly recognize the clustering of individuals within higher-level units such as cities. Second, hierarchical models are beneficial for estimating cross-level effects because all estimates are adjusted for covariates, regardless of whether they are measured at the individual or contextual level. Finally, hierarchical models can statistically 
separate the variance of the individual-level parameters from sampling variance. This attribute is important because it allows for a more powerful test of the contextual variables included in the analysis.

\section{VARIABLE DESCRIPTIONS}

\section{Dependent Variable}

The dependent variable is coded as a dichotomy. Crimes where a firearm was used by the offender were coded as one, while zero was used for nonfirearm crimes. Whether the offender used a firearm during the crime was determined by the victim or by the police. The violent crimes include murder/nonnegligent manslaughter, kidnapping/abduction, forcible rape, forcible sodomy, sexual assault with an object, forcible fondling, robbery, aggravated assault, simple assault, and extortion/Blackmail. In these types of crimes, a victim is confronted by the criminal offender; thus he or she is typically able to identify an offender's race and other demographic characteristics. The data are aggregated at the city level because this is the smallest geographical unit for which NIBRS data are made available. The use of city data enables an assessment of the conditioning effect that the racial diversity of a police department has on the likelihood that a Black offender will use a firearm in a crime.

\section{Crime Incident Variables}

The variables used to predict firearm use in the crime incident include the age, race, and sex of both the offender and victim as well as perceived use of drugs or alcohol by the offender, and the victim/offender relationship. The age of 
the offender and victim were coded as interval variables. The race $(1=$ Black and $0=$ White $)$ and $\operatorname{sex}(1=$ male and $0=$ female $)$ of the offender and victim were coded as dichotomies. The victim/offender relationship $(1=$ stranger, $2=$ acquaintance, and $3=$ intimate) was coded as an ordinal variable representing a scale of intimacy. Research finds that the age of the offender (Hirschi \& Gottfredson, 1983), age of the victim (Perkins, 1997), sex of the offender (Lauritsen, Heimer, and Lynch, 2009), sex of the victim (Lauritsen and Heimer, 2008), drug use (Goldstein, 1985), and the victim/offender relationship (Black, 1976) are all associated with violent crime.

Most of the crime incident variables were modeled as fixed or constrained to be the same for all the cities in the sample because between-city variation in these parameters was not of interest in this study. The exceptions were the intercept and the Black offender variable, which were both treated as random variables. These two variables were treated as random because this study is interested in determining whether the racial diversity of a city's police department generally influences firearm use among offenders (intercept) or the probability that a Black offender used a firearm during the commission of the criminal offense (Black offender variable).

The crime incident variables were centered by subtracting their grand means, so that the mean of each variable was zero across all cases. The centering of a variable is helpful because it acts to reduce multicollinearity and because it facilitates interpretation of a variable when it becomes the dependent variable in the aggregate-level model. In the current study, centering allows the offender's 
race variable to be interpreted as the average gap in firearm use probabilities between Black and White offenders among the cities. This variability in BlackWhite firearm use among the cities is the outcome that is explained in the between-city model.

City Variables

Several city variables were included in the between-city model. The contextual variable of theoretical interest for self-help (percentage of Black police officers) was measured as the percentage of full-time sworn officers who were Black or African American in each city during 2013. Information on Black police officers was obtained from the Law Enforcement Management and Administrative Statistics (LEMAS) (Bureau of Justice Statistics, 2013). The LEMAS survey collects data from a nationally representative sample of state and local law enforcement agencies in the U.S. A survey questionnaire in 2013 was sent to 3,336 general purpose state and local law-enforcement agencies. These organizations included 2,353 local police departments, 933 sheriff's offices, and the 50 primary state law enforcement agencies. The survey design allowed for all agencies employing 100 or more sworn personnel to be included and for smaller agencies to be sampled from strata based on the number of officers employed. Twenty-six local police departments were omitted from the survey because they were either no longer in operation, outsourced, or functioning on a part-time basis. Thirty-eight sheriff's offices were also excluded from the survey because they had no primary law enforcement jurisdiction. The final mailout total of 3,272 
agencies encompassed 2,327 local police departments, 895 sheriffs' offices, and the 50 state agencies. The LEMAS data are archived at the ICPSR.

Several additional contextual variables were also incorporated into the analysis as controls to avoid grounding suppositions on spurious or suppressed relationships. These variables were obtained from the 2010 census and included population density (persons per square mile), percentage of the population prone to criminal activity (aged 15-24), percentage of the population that is male, percentage of the population that attended college or earned an associate degree, and percentage of the population aged 18-24 that earned a bachelor's degree or higher. Research finds that population density (Sampson, 1983), age structure of the population (Cohen \& Land, 1987), percentage of the population that is male (Sun, Sung, \& Chu, 2007), and educational achievement (Lochner \& Moretti, 2004) are all correlated with violent crime. A dummy variable - whether the crime incident occurred in a southern city - was also included to control for the possibility of a southern subculture of violence and crime (Dixon \& Lizotte, 1987).

\section{MEASUREMENTS AND CALCULATIONS}

Economic inequality, racial segregation, and community disadvantage were also incorporated as contextual variables in the analysis. Economic inequality is measured by the Gini coefficient, which is a measure of the distribution of household income for all residents. It ranges from $0=$ perfect equality to $1=$ total inequality. The formula for the Gini coefficient is as follows: 


$$
\begin{gathered}
G=\frac{1}{2 n^{2} \mu} \sum_{j=1}^{m} \sum_{k=1}^{m} n_{j} n_{k}\left|\gamma_{j}-\gamma_{k}\right| \\
\mathrm{n}=\text { total number of people } \\
\mathrm{n}_{\mathrm{i}}=\begin{array}{c}
\text { number of people in income class } \mathrm{i} \\
\mathrm{y} \mathrm{i}
\end{array}=\text { income class } \mathrm{i} \\
\mathrm{u}=\text { mean income }
\end{gathered}
$$

Not only do blocked economic opportunities produce feelings of anger and resentment and perceptions of relative deprivation among the population, they also may cause some in society to engage in criminal activity (Blau and Blau, 1982). While economic inequality is thought to be the inevitable byproduct of societal development (Messner, 1989), Blacks and other racial minorities are much more likely to experience relative deprivation because of discrimination. The preponderance of evidence suggests a noteworthy positive correlation between economic inequality and the crime of homicide (Blau \& Blau, 1982; Chamlin, 1989; Messner, 1983; Sampson, 1986). For example, Jacobs and Richardson (2008) analyzed homicide data from 14 developed nations and noted that homicide rates were greatest among unequal societies. Using homicide data from 50 different countries, Lee and Bankston (1999) also reported a positive nexus between economic inequality and homicide rates. Parker and McCall (1999) found that economic deprivation significantly influenced the rates of Blackon-White homicide in the U.S. Finally, Lee, Maume, and Ousey (2003) examined data from 1,746 counties in the U.S. and noted that in metropolitan areas specifically, socioeconomic disadvantage and poverty concentration elevated homicide rates. 
Racial segregation is measured using the White-Black dissimilarity index, which is a commonly used measure of racial segregation between two groups and reflects their relative distributions across neighborhoods within the same city. It measures the percentage of one group that would have to move across neighborhoods to be distributed the same way as the second group. The measure is symmetrical, so this interpretation can apply to either group. A dissimilarity index of 0 indicates conditions of total integration while a dissimilarity index of 100 denotes conditions of total segregation such that the members of one group are in completely different neighborhoods than the second group. The formula for the White-Black dissimilarity index is as follows:

$$
\begin{gathered}
D=\frac{1}{2} \sum_{i=1}^{n}\left|\frac{w_{i}}{W_{\tau}}-\frac{b_{i}}{B_{\tau}}\right| \\
\mathrm{n}=\text { number of census tracts } \\
\mathrm{W}_{\mathrm{i}}=\text { number of Whites in census tract } \mathrm{i} \\
\mathrm{W} \tau=\text { total number of Whites in city } \\
\mathrm{b}_{\mathrm{i}}=\text { number of Blacks in census tract } \mathrm{i} \\
\mathrm{B} \tau=\text { total number of Blacks in city }
\end{gathered}
$$

Approximately $62 \%$ of Blacks living in the U.S. reside in racially segregated areas (Krivo, Peterson, \& Kuhl, 2009). Black citizens residing in these racially segregated neighborhoods are exposed to a multitude of social and economic disadvantages (Krivo et al., 2009; Peterson \& Krivo, 1993; Wilson, 1987). Both formal and informal social controls are limited in these areas (Anderson, 1990; Peterson et al., 2005). Inadequate police protection and subpar police response times for citizen assistance are commonplace in racially segregated areas. In 
addition to the neglect shown by law enforcement, racially segregated residential areas are often ignored by city officials, which exacerbates conflict and impedes the establishment of law and order (Krivo et al., 2009). The lack of social, financial, and institutional resources in these racially segregated neighborhoods also acts to impede informal mechanisms of social control by decreasing Black citizens' ability to establish anti-crime community initiatives such as neighborhood watch groups, volunteer patrols, and crime hotlines (Peterson \& Krivo, 1993).

A number of empirical studies report a positive correlation between racial residential segregation and violence (Krivo et al, 2009; Logan \& Messner, 1987; Peterson \& Krivo, 1993; Sampson, 1985; South \& Felson, 1990). Logan and Messner (1987) analyzed suburban crime patterns and observed a positive relationship between residential segregation and homicide. Using arrest data, Sampson (1985) found that racial residential segregation had a strong indirect effect on urban homicide. Peterson and Krivo (1993) analyzed the impact of racial segregation on homicide victimization among Blacks and concluded that social isolation, which is sometimes used as a measure of residential racial segregation, contributed to higher rates of Black homicide. In another study, Krivo et al., (2009) examined the roles of city segregation, neighborhood disadvantage, and racial composition on violent crime using data obtained from the National Neighborhood Crime Study. Their analysis of 7,622 neighborhoods drawn from 79 cities across the U.S. showed that rates of violence were significantly higher in racially segregated cities. 
Community disadvantage was calculated using factor scores from a principal component analysis of four variables: a) percentage of the population that is Black or African American, b) percentage of the civilian labor force that is unemployed, c) percentage of households headed by a single female with children, and d) percentage of residents below the poverty level in 2009. Research finds that the Black population percentage (Bailey, 1984), unemployment (Parker \& McCall, 1999), family disruption (Sampson \& Groves, 1989), and poverty (Rogers \& Pridemore, 2013) are all associated with violent crime. Greater disadvantage is indicated by a higher score on the composite measure. Although the five-year lag most likely introduces some errors into the measurement of these variables, their inclusion as a composite control variable provides important information about social conditions within each city. All the city variables were grand-centered prior to their inclusion in the multilevel model. The results from the principal component analysis for the community disadvantage index are shown in Table 1. The means, standard deviations, and definitions for all the variables used in this study are presented in Table 2.

\section{TABLE 1. PRINCIPAL COMPONENT ANALYSIS FOR COMMUNITY DISADVANTAGE}

\begin{tabular}{lrr}
\hline & $\begin{array}{c}\text { Percent of } \\
\text { Variance }\end{array}$ & Component \\
\hline Percent of population that is Black or African American & 75.916 & .817 \\
Percent of civilian labor force that is unemployed & 11.999 & .909 \\
Percent of households headed by a single female with & 6.986 & .899 \\
children & & 5.098 \\
Percent of population below the poverty line in 2009 & .857 \\
\hline
\end{tabular}


TABLE 2. MEANS, STANDARD DEVIATIONS, AND DEFINITIONS FOR THE VARIABLES USED IN THE ANALYSIS

\begin{tabular}{|c|c|c|c|}
\hline Variable & Mean & $\begin{array}{l}\text { Standard } \\
\text { Deviation }\end{array}$ & Definition \\
\hline Firearm use & .04 & .19 & $\begin{array}{l}\text { Coded } 1 \text { if a firearm was involved in the } \\
\text { incident, } 0 \text { otherwise. }\end{array}$ \\
\hline Drug use & .11 & .31 & $\begin{array}{l}\text { Coded } 1 \text { if the offender was suspected of } \\
\text { using drugs or consuming alcohol during } \\
\text { or shortly before the incident, } 0 \\
\text { otherwise. }\end{array}$ \\
\hline Intimacy & 2.17 & .57 & $\begin{array}{l}\text { Coded } 1 \text { if the victim was a stranger, } 2 \\
\text { acquaintance, and } 3 \text { intimate. }\end{array}$ \\
\hline Male offender & .76 & .43 & Coded 1 if the offender is male, 0 female. \\
\hline Male victim & .33 & .47 & Coded 1 if the victim is male, 0 female. \\
\hline Black offender & .55 & .50 & $\begin{array}{l}\text { Coded } 1 \text { if the offender is Black or African } \\
\text { American, } 0 \text { White. }\end{array}$ \\
\hline Black victim & .48 & .50 & $\begin{array}{l}\text { Coded } 1 \text { if the victim is Black or African } \\
\text { American, } 0 \text { White. }\end{array}$ \\
\hline Offender age & 32.58 & 12.88 & Age of the offender in years. \\
\hline Victim age & 32.58 & 14.31 & Age of the victim in years. \\
\hline $\begin{array}{l}\text { Percent Black } \\
\text { officers }\end{array}$ & .08 & .10 & $\begin{array}{l}\text { Percent of full-time sworn officers that } \\
\text { are Black or African American (based on } \\
\text { LEMAS 2013). }\end{array}$ \\
\hline $\begin{array}{l}\text { Population } \\
\text { density }\end{array}$ & $1,871.54$ & $1,409.10$ & Population per square mile of land area. \\
\hline Southern city & .28 & .45 & $\begin{array}{l}\text { Coded } 1 \text { if the city is in the South, } 0 \\
\text { otherwise. Controls for the possibility of a } \\
\text { southern subculture of violence and } \\
\text { crime. }\end{array}$ \\
\hline Percent 15-24 & 14.71 & 4.33 & $\begin{array}{l}\text { Percent of the population prone to } \\
\text { criminal activity (ages 15-24). }\end{array}$ \\
\hline Percent male & 48.76 & 1.21 & Percent of the population that is male. \\
\hline Percent college & 45.32 & 8.92 & $\begin{array}{l}\text { Percent of the population that attended } \\
\text { college or earned an associate's degree. }\end{array}$ \\
\hline $\begin{array}{l}\text { Percent } \\
\text { bachelors }\end{array}$ & 12.70 & 7.35 & $\begin{array}{l}\text { Percent of the population } 18-24 \text { that } \\
\text { earned a bachelor's degree or higher. }\end{array}$ \\
\hline $\begin{array}{l}\text { Economic } \\
\text { inequality }\end{array}$ & .45 & .04 & $\begin{array}{l}\text { A measure of the distribution of } \\
\text { household income for all residents (Gini } \\
\text { coefficient). Ranges from } 0=\text { perfect } \\
\text { equality to } 1 \text { = total inequality. }\end{array}$ \\
\hline
\end{tabular}




\begin{tabular}{lll}
$\begin{array}{l}\text { Racial } \\
\text { segregation }\end{array}$ & $35.04 \quad 14.78 \begin{array}{l}\text { The White-Black dissimilarity index ranges } \\
\text { from } 0=\text { complete integration to } 100= \\
\text { complete segregation. }\end{array}$ \\
$\begin{array}{l}\text { Community } \\
\text { disadvantage }\end{array}$ & $\begin{array}{l}\text { Factor scores from a principal component } \\
\text { analysis of four variables: a) percent of } \\
\text { population that is Black or African }\end{array}$ \\
& $\begin{array}{l}\text { American, b) percent of civilian labor force } \\
\text { that is unemployed, c) percent of } \\
\text { households headed by a single female } \\
\text { with children, and d) percent of } \\
\text { population below the poverty line in } 2009 . \\
\text { A high score indicates greater } \\
\text { disadvantage. }\end{array}$ \\
\hline
\end{tabular}




\section{CHAPTER IV}

\section{RESULTS}

The multilevel analysis was begun by estimating a within-city regression model using the crime incident variables to predict firearm use in a crime. All the variables were constrained to be the same across cities in the sample, except for the intercept and the Black offender variable. These two variables were allowed to vary between the different cities so that the size and significance of their estimated variances could be estimated so as to ascertain whether it would be beneficial to use aggregate-level variables to predict between-city differences in their slopes. The following equation was employed for the within-city model:

$$
\begin{gathered}
\log \left[\rho_{i j} /\left(1-\rho_{i j}\right)\right]=\beta_{0 j}+\beta_{1 j} \text { Drugs }_{i j}+\beta_{2 j} \text { Intimacy }_{i j}+\beta_{3 j} \text { Omale }_{i j} \\
+\beta_{4 j} \text { Vmale }_{i j}+\beta_{5 j} \text { Oblack }_{i j}+\beta_{6 j} \text { Vblack }_{i j}+\beta_{7 j} \text { Oage }_{i j}+\beta_{8 j} \text { Vage }_{i j}+\varepsilon_{i j}
\end{gathered}
$$

where $\rho_{i j}$ is the probability that crime $i$ from city $j$ is a firearm crime, $\beta_{i j}$ represents the coefficients for the crime incident variables, and $\varepsilon$ is the error term.

\section{Within-City Analysis}

The results for the within-city model are presented in Table 3 . These findings show that all the crime incident independent variables have a strong effect on firearm use. The odds ratios are included in Table 3 because they are more intuitive than the coefficients themselves. To illustrate, the odds ratio for a male offender is 3.7 . This figure indicates that male offenders are 3.7 times more likely than female offenders to use a firearm in a crime. Table 3 also shows that firearm 
incidents are more likely to occur when the victim is a male, when the victim is Black, when the incident involves a younger offender, and when the victim is older. These findings are supported in the literature. Prior studies report that males are more likely to be both the offender and victim of violent crimes (Circo, Pizarro, \& McGarrell, 2018), that Blacks tend to be disproportionately represented among firearm victims (Wintemute, 2015), and that younger offenders tend to use firearms against older victims (Circo et al., 2018).

Regarding an offender's race, results show that Blacks are more likely than Whites to use guns in their crimes. The odds of utilizing a firearm during the commission of a crime were about 52\% ( $p \leq .001)$ higher for Black than White offenders. This percentage change in the odds was computed using the following formula: 100 ( $\left.e^{b}-1\right)$. Additionally, and contrary to some previous studies (Branas, Han, \& Wiebe, 2016), offenders believed to be on drugs or alcohol at the time of their crime were $45 \%$ less likely to use a firearm. Equally interesting and contrary to some prior research (Siegel et al., 2014) is that firearms were much more likely to be employed against strangers. In fact, as intimacy increased, the likelihood of a firearm being used in a crime decreased by approximately $63 \%$ ( $p$ $\leq .001)$. This finding runs directly counter to Donald Black's (1983; 1987) assertion that self-help is most likely to transpire among intimates. The mobilization of law is speculated to be attenuated as relational proximity increases because citizens often believe that law enforcement is hesitant to intervene in domestic disputes and because there is an overwhelming desire among citizens for privacy and autonomy. 
The results also show that the estimated between-city variances for the intercept slope $(.490, P<.001)$ and for the Black offender slope $(.069, P=.028)$ are statistically noteworthy. These findings indicate that there is substantial variation among the cities regarding firearm use. Even after controlling for the crime incident variables, criminal offenders are more likely to use firearms in some cities than in others. Black offenders also have an enhanced tendency, as compared to White offenders, to use firearms in certain cities.

TABLE 3. WITHIN-CITY PROBABILITY OF FIREARM USE RESULTS

\begin{tabular}{lrrr}
\hline Outcome Predictor & Coefficient & Standard Error & \multicolumn{1}{c}{ Odds Ratio } \\
\hline Intercept & -4.027 & .052 & .018 \\
Drug use & $-.599^{* * *}$ & .085 & .549 \\
Intimacy & $-.989^{* * *}$ & .061 & .372 \\
Male offender & $1.300^{* * *}$ & .049 & 3.669 \\
Male victim & $1.056^{* * *}$ & .050 & 2.874 \\
Black offender & $.422^{* * *}$ & .046 & 1.524 \\
Black victim & $.344^{* * *}$ & .067 & 1.411 \\
Offender age & $-.007^{* * *}$ & .002 & .993 \\
Victim age & $.005^{* * *}$ & .001 & 1.005 \\
\hline
\end{tabular}

NOTES: ${ }^{*} \mathrm{p} \leq .05 ;{ }^{* *} \mathrm{p} \leq .01 ;{ }^{* * *} \mathrm{p} \leq .001$ (two-tailed tests). Population-average model with robust standard errors.

\section{Between-City Analysis}

The purpose of the between-city analysis is to use the city-level variables to attempt to explain why this variability in firearm crime among the cities exists, even after accounting for the crime incident variables. The question of theoretical relevance being addressed in the between-city analysis is whether the contextual variables - particularly the racial diversity of a city's police force - influence the 
likelihood of firearm being used in a crime generally and the likelihood of a firearm being used in a crime committed by a Black offender. The between-city model is written as:

$$
\begin{aligned}
& \beta_{0 j}=\gamma_{00}+\gamma_{01} \text { Percent Black Officers } \text { Of }_{j}+\gamma_{02} \text { Population Density }_{j}+
\end{aligned}
$$

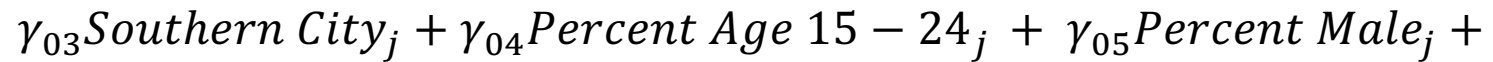

$$
\begin{aligned}
& \gamma_{06} \text { Percent College }_{j}+\gamma_{07} \text { Percent Bachelors }_{j}+ \\
& \gamma_{08} \text { Economic Inequality }_{j}+\gamma_{09} \text { Racial Segregation }_{j}+ \\
& \gamma_{10} \text { Community Disadvantage }_{j}+u_{0 j} \text {, }
\end{aligned}
$$

where, for each city $j, \beta_{0}$ represents the intercept from the crime incident model, $\gamma_{0}$ represents the city variables, and $u$ is the error term. The coefficients for this model are reported in Table 4.

Table 4 shows that the coefficients for all the fixed crime incident variables remain unchanged from the within-county analysis. Table 4 further shows that there is no statistically significant effect of the racial diversity of a police department on the use of firearms in crimes generally. Firearm crimes are not more or less likely to occur in cities with a racially diverse police department. The results also show that offenders in southern cities are 1.4 times more likely to use a firearm than offenders in other parts of the country. This finding is wellsupported in the literature as the southern region of the country typically experiences higher rates of both firearm ownership and gun-related deaths (Lemieux, 2014). The results further reveal that none of the other contextual variables play an important role in the equation.

Table 4 also displays the results pertaining to whether the percentage of Black police officers working in a city moderates the relationship between an 
offender's race and firearm use. The results for the multilevel analysis show that, for a one unit increase in the percentage of Black police officers, the difference in the likelihood of firearm use between Black and White criminal offenders decreases by $67 \%$. In other words, while Black offenders typically commit more crimes with firearms than White offenders $(41 \%$ more firearm crimes in the between-city model), this racial difference in firearm use between Blacks and Whites decreases by $67 \%$ for a one unit increase in the percentage of Black police officers employed in a city. This finding is clearly consistent with self-help theory and supports Black's (1983) claim concerning law mobilization. It thus appears that a more racially diverse police department is better able to attenuate personal conflict in the community by minimizing the use of firearms among Black citizens.

Table 4 further shows that the variables population density, southern city, and population ages 15-24 are salient in explaining firearm use among Black offenders. Black offenders are more likely to use firearms in less densely populated cities, non-southern cities, and cities with a higher percentage of young people. None of the other city variables played a salient role in the model.

The estimated between-city variance for the intercept slope $(.490, P<.001)$ in Table 4 is sizeable and statistically significant. This finding indicates that a substantive amount of between-city variability still exists among the cities regarding the general use of firearms in crimes. Other aggregate-level variables are necessary to account for this unexplained variation, although it is unclear exactly which variables are needed. In contrast, the estimated between-city 
variances for the Black offender slope $(.049, P=.183)$ is no longer salient with the inclusion of the city-level variables. This finding suggests that no other crime incident or city-level variables are needed to explain city variation in the probability that a Black offender will use a firearm during the commission of his or her crime. 
TABLE 4. BETWEEN-CITY PROBABILITY OF FIREARM USE RESULTS

\begin{tabular}{|c|c|c|c|}
\hline Outcome Predictor & Coefficient & $\begin{array}{c}\text { Standard } \\
\text { Error }\end{array}$ & $\begin{array}{l}\text { Odds } \\
\text { Ratio }\end{array}$ \\
\hline \multicolumn{4}{|l|}{ Firearm use differential } \\
\hline Intercept & -4.134 & .049 & .016 \\
\hline Percent Black officers & 1.332 & .692 & 3.787 \\
\hline Population density & $-.024 e-3$ & $.045 e-3$ & 1.000 \\
\hline Southern city & $.338 * *$ & .125 & 1.402 \\
\hline Percent 15-24 & -.022 & .019 & .978 \\
\hline Percent male & .008 & .043 & 1.008 \\
\hline Percent college & .015 & .009 & 1.015 \\
\hline Percent bachelors & -.015 & .010 & .985 \\
\hline Economic inequality & .528 & 1.834 & 1.695 \\
\hline Racial segregation & .003 & .005 & 1.003 \\
\hline Community disadvantage & .033 & .089 & 1.034 \\
\hline Drug use & $-.595 * * *$ & .076 & .551 \\
\hline Intimacy & $-.996 * * *$ & .052 & .369 \\
\hline Male offender & $1.298 * * *$ & .045 & 3.663 \\
\hline Male victim & $1.059 * * *$ & .044 & 2.884 \\
\hline \multicolumn{4}{|l|}{$\begin{array}{l}\text { Black-White offender firearm use } \\
\text { differential }\end{array}$} \\
\hline Intercept & $.344^{* * *}$ & .046 & 1.411 \\
\hline Percent Black officers & $-1.104^{* *}$ & .411 & .331 \\
\hline Population density & $-.089 e-3^{*}$ & $.039 \mathrm{e}-3$ & 1.000 \\
\hline Southern city & $-.272 * *$ & .109 & .762 \\
\hline Percent 15-24 & $.051^{*}$ & .023 & 1.053 \\
\hline Percent male & -.072 & .039 & .931 \\
\hline Percent college & $-.165 e-3$ & .004 & 1.000 \\
\hline Percent bachelors & .011 & .011 & 1.011 \\
\hline Economic inequality & .924 & 1.796 & 2.518 \\
\hline Racial segregation & .006 & .005 & 1.006 \\
\hline Community disadvantage & .096 & .090 & 1.101 \\
\hline Black victim & $.336 * * *$ & .062 & 1.400 \\
\hline Offender age & $-.007 * * *$ & .002 & .993 \\
\hline Victim age & $.005 * * *$ & .001 & 1.005 \\
\hline
\end{tabular}

NOTES: ${ }^{*} \mathrm{p} \leq .05 ; * * \mathrm{p} \leq .01 ; * * * \mathrm{p} \leq .001$ (two-tailed tests). Population-average model with robust standard errors. 


\section{CHAPTER V \\ DISCUSSION}

This study sought to investigate whether the racial diversity of a city's police force influences whether a Black offender uses a firearm during the commission of a crime. The theoretical premise of this study was the self-help hypothesis. The results produced in a multilevel analysis furnish unambiguous empirical support for self-help theory. The findings show that, when controlling for a variety of theoretically relevant crime incident and city variables, an increased percentage of Black police officers has a negative effect on the probability of a Black criminal using a firearm. As the racial diversity of a city's police department increases, Black offenders are less likely to use a firearm in a crime. Interestingly, the results indicate that the overall likelihood of a firearm crime transpiring is not impacted by the racial diversity of a city's police department. Rather, firearm crimes committed by Black offenders are affected.

\section{DESCRIPTIVE REPRESENTATION}

Such findings are in accord with the central tenets of self-help theory and speak directly to the veracity of the claim that Black citizens are more likely to have a positive perception of institutional legitimacy and fairness when the police officers patrolling their neighborhoods are racially diverse. People make a voluntary and conscious decision to obey laws (Easton, 1975) and the directives made by police (Black, 1983). Thus, when citizens view a governmental institution such as the police force as legitimate, good will is enhanced and people have a greater incentive to obey the law (Scherer \& Curry, 2010). This 
phenomenon is known as descriptive representation, the logic of which is that the racial, ethnic, and gender composition of a political institution must mirror the population it represents for marginalized groups in society to view the institution as legitimate (Mansbridge, 1999). The theory of descriptive representation suggests that institutional legitimacy is not necessarily determined by procedural justice or by substantive representation but, rather, by what is seen by the population because persons with similar backgrounds are assumed to have shared values and similar experiences (Scherer \& Curry, 2010). Mansbridge (1999) surmises this notion with her statement: "Black legislators represent Black constituents, [and] women legislators represent women..." (Mansbridge, 1999, p. 629). Often, when a person of a similar background is in a position of authority, it gives racial minorities someone to identify with while simultaneously conveying the impression that "I am one of you" (Fenno, 1978, p. 56).

There are undeniable benefits for having adequate racial minority representation in governmental institutions. Banducci, Donovan, and Karp (2004) report that greater minority representation in government results in higher approval ratings of governmental responsiveness to the citizenry and increases contact between Black citizens and their Black political representatives. Black citizens also exemplify more pride and greater trust in their government when Blacks are elected to public office and when they hold various political administrative positions (Gurin, Hatchet, \& Jackson, 1989; Preston, 1978). Bobo and Gilliam (1990) further show that Blacks are more likely to vote in areas where there are a greater number of Black elected officials. Additionally, Bobo 
and Gilliam (1990) found that Blacks living in cities with a Black mayor held more favorable views of their government and justice system. Finally, Scherer and Curry (2010) found that descriptive representation enhanced Black citizens' perceptions of institutional legitimacy, irrespective of their political ideologies or affiliations.

Descriptive representation is rooted primarily in shared experiences and familiarity because people possessing similar characteristics often have similar life histories. For example, residents of small towns elect officials to public office who were born and raised in the same community as voters because these individuals have similar values and concerns, lack ulterior motives or hidden agendas, and have a genuine desire to help their communities. These elected officials are also seen by their neighbors as exceedingly knowledgeable on local issues and not as inexperienced as ill-informed outsiders. Thus, based on the logic associated with descriptive representation, Black citizens tend to have a favorable view of an institution if the members of the institution are also Black because these individuals share the same physical characteristics and, because of this physical similarity, probably have similar life experiences.

Prolific writer and community activist James Baldwin (1965, p. 65) aptly articulated this position in his discussion of the discontent felt by Black residents when mostly White police officers patrolled their neighborhoods:

"The only way to police a ghetto is oppressive. None of the Police Commissioner's men, even with the best will in the world, have any way of understanding the lives led by the people: they swagger about in twos and 
threes patrolling. Their very presence is an insult, and it would be, even if they spent the entire day feeding gum drops to children."

Baldwin's assertion supports the tenets of descriptive representation because he was referring to White police officers' inability to empathize with or relate to people of color. He further acknowledges that even the most well-intentioned White officer is unable to connect with Black citizens in the ghetto where crime and violence are often rampant. The inability of White police officers to connect with the Black community erodes both good will and trust, which ultimately compromises the legitimacy of the police and serves as a disincentive for Black citizens to obey the laws. Hence, it stands to reason that Blacks are going to be more likely to use a firearm in a crime to resolve a personal dispute as opposed to mobilizing police when they perceive the police, who are tasked with maintaining order and aiding the public, to be racially different and ignorant of their culture.

\section{RESIDENCY}

A more racially diverse police department may also be better able to address problematic behavior and citizen disagreements in minority communities before they escalate into violence. Indeed, research has consistently shown that both Black and Hispanic officers are more likely than White officers to reside in the communities that they patrol. Among the biggest U.S. cities with the largest Black populations, there is a distinct difference between where Black and White police officers live. In Detroit, for example, $57 \%$ of Black police officers live and work within city limits as compared to only $8 \%$ of White police officers (Silver, 2014). 
Similar statistics are reported for other cities with relatively large Black populations such as Memphis, Tennessee, Baltimore, Maryland, Birmingham, Alabama, and Jackson, Mississippi.

Several cities have instituted or upheld residency requirements in recognition of this situation, which mandate that police officers live within city limits or within a certain distance of city limits. While residency requirements remain both controversial and unpopular among police, and the number of cities mandating these requirements is declining because of legal challenges (Herring \& Potter, 2018), they are still thought to be effective in increasing citizen confidence in law enforcement (Smith, 1980) and in furthering community interests (Murphy \& Worrell, 1999). The President of Pittsburgh's Alliance for Police Accountability maintains that a residency requirement for police ensures that "police officers build real relationships with the people they serve and treat them as human beings" (Herring \& Potter, 2018, para. 15). Increasing the number of Black police officers would certainly help to negate the need for legally questionable residency requirements because many Black and Hispanic police officers already reside in the communities that they patrol. A police officer voluntarily residing in the same community that he or she patrols has the potential to remove the "us versus them" mentality and promote inclusion, not just because of sheer presence, but also because of a personal desire to remain a member of the community. The close presence of police in the community also provides local residents with easy and fast access to legal protection. 
A third plausible explanation for the observed decrease in the likelihood of Black firearm crime in cities with a more racially diverse police force pertains to the positive effect that Black police officers may be having on White police officers' attitudes toward Black citizens. While the first 150 years of policing in the U.S. was characterized by discrimination, racism, violence, and open hatred towards Black citizens, policing today has evolved, so some extent (Futterman, et al., 2017; Smith \& Alpert, 2007). Nevertheless, while overt racism by police has been quelled to a large degree, many White police officers still struggle with unconscious racial bias that might result in them unfairly targeting people of color.

\section{UNCONSCIOUS BIAS}

Although unfortunate, it is quite possible that White police officers interact with Black citizens based on a set of subconscious, preconceived notions regarding culpability, threat, and worthiness (Fridell \& Lim, 2016). Social psychologists frequently find that unconscious bias affects decision making and social interactions (Charbonneau, Spencer, \& Glaser, 2017; Lyon, 2011). It is well documented that children subscribe to stereotypes long before they acquire critical analysis skills or develop personal beliefs (Charbonneau et al., 2017;

Devine, 1989; Katz, 1976). In general, stereotypes have greater recollection power because they are far more accessible than even personal beliefs (Beeghly, 2015; Devine, 1989). As such, even a well-intentioned White officer may succumb to racial bias - especially in the absence of a racially diverse police force. This situation is exacerbated by a general belief that Blacks are 
violent, criminal, and/or dangerous. Because implicit bias occurs on a subconscious level, an individual does not need prejudicial attitudes or feelings of hatred toward a particular ethnic group to act on embedded stereotypes (Fiske, 2010). Richardson (2010, p. 2039) notes that, "in the policing context, implicit stereotypes can cause an officer who harbors no conscious racial animosity and who rejects using race as a proxy for criminality to unintentionally treat individuals differently based solely upon their physical appearance."

An array of studies indicate that unconscious bias affects police officers' interactions with citizens. For example, James, Klinger, and Vila (2014) examined subconscious threat related to a suspect's race and found that unconscious bias was predictive of police shootings. From a neurological perspective, a suspect's race significantly predicted threat arousal because participants experienced greater alpha suppression when they encountered an armed Black suspect. Even in the absence of a weapon, participants still displayed stronger threat responses when confronting Black criminal suspects. In another study, Stone et al. (2010) analyzed fatal police-on-police shootings over a 28 -year period. During the study period, 10 off-duty officers were fatally shot by an on-duty officer. Eight of the 10 police officers fatally shot were Black. Although police-on-police shootings are relatively uncommon, Stone and his associates were still able to find evidence of racial disparity in the occurrence of such shootings. Additionally, Gabrielson, Jones, and Sagra (2014) found that Black males were 21 times more likely than White males to be shot and killed by a White police officer. Not only are Blacks more likely to be the victim of deadly 
police force (Stone et al, 2010; Gabrielson, 2014; James et al., 2014), but they are also stopped and searched more frequently by White officers (Fridell \& Lim, 2016; Ayres \& Borowsky, 2008; Richardson, 2010).

Even more disturbing is that most of these stops of Black citizens fail to culminate in an arrest (Fridell \& Lim, 2016; Richardson, 2010). Ayres and Borowsky (2008) analyzed outcomes from the Los Angeles Police Department pertaining to the arrest efficiency of stop-and-frisk. They found that Blacks were $42 \%$ less likely to have a weapon, $25 \%$ less likely to have drugs, and $33 \%$ less likely to have other contraband than were Whites. Similar results have emerged for New York City (Fridell \& Lim, 2016; Herbert \& Crow, 2009; Richardson, 2010). In fact, stops of Black citizens were so pervasive and unsuccessful in New York City that District Court Judge Shira A. Scheindlin wrote: "Unconscious bias could help explain the otherwise puzzling fact that NYPD officers check 'Furtive Movements' in $48 \%$ of the stops of Blacks and $45 \%$ of the stops of Hispanics, but only $40 \%$ of the stops of Whites. There is no indication that Black people's movements are objectively more furtive than the movements of White people" (Floyd et al., 2013, p. 45).

A racially diverse police force might also help White police officers to more effectively interact with Black citizens as a history of racial discrimination and misuse of authority often characterizes communities of color (Giwa, 2018). Thus, through the acquisition of valuable knowledge and insight derived from their interaction with Black officers regarding how to relate, empathize, de-escalate conflict, and efficiently mollify problems in the Black community, White officers 
can become better equipped to serve disadvantaged areas. Additionally, research shows that Black officers have more favorable opinions of communitystyle policing (as compared to more traditional and legalistic methods) and its ability to control crime and increase rapport among Black citizens (Brown \& Frank 2006; Weisburd, Greenspan, Hamilton, Williams, \& Bryant, 2000). The National Crime Prevention Council (1995) also noted that having a more racially and ethnically diverse agency helped improve police-community interactions. Moreover, having a diversified department influences police officers' consciousness regarding race relations. Thus, in more racially diverse police agencies, both Black and nonBlack officers tend to be more aware of activities that could have detrimental effects on the department, increase citizen hostility, and erode community trust (Brown \& Frank, 2006; Shusta, Levine, Harris \& Wong, 1995).

Several policing studies buttress this logic by finding that Black police officers tend to have a better rapport with Black citizens than White police officers do, which, in turn, helps to amplify Black citizens' trust and faith in the police. This is not a new concept. Kelly and Farber (1974) analyzed officer attitudes several decades ago and observed that Black officers were more likely to be labeled as "responsive" to the needs of disadvantaged communities as compared to their White counterparts. Barlow and Barlow (2000) further noted that increasing the number of Black police officers resulted in an amplification of Black citizens' approval of law enforcement as a state instrument of social control. Furthermore, Sun and Payne (2004) found that White police officers were less likely than their 
Black counterparts to provide supportive activities in disadvantaged communities of color. They also observed that Black officers were more effective than White officers when interacting with Black citizens. Bolton and Feagin (2004) argued that, because of shared life experiences, Black officers were more intuitive and understanding than their White counterparts of the problems regarding racism, discrimination, and prejudice. Black officers were thus better able to "operate in the best interest of controlling street crime, as well as in strengthening of Black communities by helping to overcome some of the harsh consequences they experience in their communities" (Bolton \& Feagin, 2004, p. 251). In a more recent study that analyzed data derived from the Project on Policing Neighborhoods, Boyd (2010) found that Black police officers were more likely than White officers to respond positively to quality-of-life issues in communities of color. These quality-of-life issues included neighbor and family disputes, improving neighborhood conditions, and addressing public fear of crime.

Though one may argue that the effectiveness of Black police officers in disadvantaged communities is attributed to their race and subsequent ability to connect with the citizenry, it is certainly possible that having a large number of Black police officers working in a police department acts to reshape the department's organizational culture by enhancing race-relations. Policing is a unique career endeavor that is often accompanied by uncommon stressors. As front-line responders, police typically find themselves enmeshed in a unique subculture because of their isolation from the general populace (Coleman, 1987). The police subculture not only reinforces both acceptable and unacceptable 
behavior, but it also acts to shape an individual's perspectives (Chappell \& Piquero, 2004).

The reinforcement of the positive or negative behavior of a police officer depends on a specific department because the interdepartmental culture of an agency is thought to directly impact socialization and training directly (Nowacki \& Spencer, 2019). Skolnick (2011) found that the effects of organizational structure were so strong among law enforcement officers that individual identities and differences often succumbed and conformed to departmental beliefs. Others have reached similar conclusions. In a longitudinal study of police recruits in Philadelphia, Savitz (1970) found that recruits' attitudes conformed more to the acceptable norms and values of the police department as they became more immersed in the police subculture.

Within the police subculture, high regard and peer approval are highly valued among police officers (Garduno, 2019; Chappell \& Piquero, 2004; Millie \& Das, 2016). The organizational culture is reinforced because it is expedient for an officer to behave in a prescribed manner to appease his or her fellow officers (Herbert, 1998). Thus, in more racially diverse police departments, White police officers may both consciously and unconsciously act in a manner to placate their fellow Black officers. Cordner (2017) asserts that organizational membership has a much greater influence on the behavior and perceptions of police officers than their personal beliefs. A study by Nowacki and Spencer (2019) highlights the importance of racial diversity in and among various police departments. More specifically, they analyzed traffic citation inconsistencies among Black and White 
citizens. They found that the racial disparity in the issuance of traffic citations was significantly smaller for police departments where the racial demographics of the department more closely resembled the racial demographics of the community.

In recent years, social psychologists have advanced the theory of intergroup contact (Allport 1954; Cook, 1984; Pettigrew, Tropp, Wagner, \& Christ, 2011) as a means of reducing implicit bias, racial anxiety, and stereotype threat (Godsil, Tropp, Goff, \& Powell 2014). Because research suggests that some White officers perceive Blacks as being more potentially dangerous than Whites, one way to mollify this racial bias is to increase the frequency with which White officers interact with persons of color. Studies find that interacting on a personal basis with different racial groups has the potential to diminish unconscious bias (Dasgupta \& Rivera, 2006). Such a personal connection is necessary to promote both inclusion and empathy (Voci \& Hewston, 2003). Thus, it stands to reason that White officers in more racially diverse police departments have less implicit bias because they are consistently afforded the opportunity to interact with persons of color who challenge popular stereotypes.

Being afforded the opportunity to interact with persons of color can also lead to the development of friendships that might otherwise not occur. Interracial friendships are deemed to be a powerful tool for decreasing racial bias and for promoting positive attitudes among diverse groups (Brown \& Hewston, 2005). The preponderance of evidence supports this position. For example, even during the race riots, Lee and Humphrey (1968) found that Black and White citizens who knew each other and who had developed relationships did not participate in the 
violence and often volunteered to assist their neighbors in mitigating racial conflict. While intergroup contact is not a panacea for the attenuation of unconscious bias and/or prejudice, research tends to support its effectiveness.

It seems likely that an increase in the racial diversity of a police department has a positive influence on its organizational subculture. Greater departmental cohesion and empathy have the potential to impact citizen interactions which subsequently increases both institutional trust and the decision among citizens to mobilize law instead of relying on self-help. Using an online survey of members of the National Association of Black Law Enforcement Officers, Wilson, Wilson, and Thou (2015) sought to ascertain if Black police officers believed their presence had a significant impact on minority relations at their agency. The results showed that respondents believed their presence influenced organization culture and improved perceptions of professional worth for racial minorities and for minority cultures. Hence, because of increased racial minority presence in police departments, positive and supportive interactions between White police officers and persons of color in the community may be enhanced. In sum, then, prolonged interaction and the development of personal connections and friendships between White and Black police officers not only improves organizational morale and ethics but, provides an explanation for why cities with more racially diverse police departments are less likely to have Black offenders use firearms during the commission of their crimes. 


\section{Policy Implications}

The findings reported in this study have important policy implications.

Reducing violent crime in minority communities, especially crimes involving the use of firearms, has always been a challenge for policymakers. Most efforts have been directed at escalating policing in predominantly Black neighborhoods and in intensifying the severity of punishment to deter individuals from committing crimes with guns. The first approach is based on the logic that hardnose policing tactics such as the widespread use of stop-and-frisk will reduce violent crime by decreasing offenders' ability to carry firearms in public settings. The second strategy theorizes that individuals will be less likely to use a firearm in a crime if criminal penalties are severe. Evidence regarding the effectiveness of these two approaches is mixed. However, the results of the present study indicate that there is an alternative approach that can be implemented by policymakers to actualize a substantive reduction in firearm use among Black citizens.

First, and most importantly, this study has highlighted the importance of hiring more Black police officers to help attenuate the use of firearms by Black criminal offenders. Although the racial composition of police departments began to change during the mid-1960s, this transformation was attributed largely to the inability of many White officers to efficiently mollify the racial conflict, violence, and urban rioting that transpired from the efforts of disenfranchised citizens to acquire civil rights (Schneider, 2014). Consequently, the rise in the number of Black police officers during the civil rights era was intended to assist with civil unrest rather than to improve racial diversity and inclusion. 
Although many police departments today are much more racially diverse than in previous years, racial disparity still exists. Indeed, only about $12 \%$ of police officers are currently Black (Gustafson, 2013; Reaves, 2015). According to the most recent comprehensive data available from the Bureau of Justice Statistics, many of the largest local police departments in the U.S. are still overwhelmingly White (Reaves, 2010). For example, while the population of Charleston, South Carolina is almost $50 \%$ Black, its police force is only $20 \%$ Black. In Ferguson, Missouri, where unarmed Black teen Michael Brown was fatally shot by a White officer, $67 \%$ of the citizens are Black while $87 \%$ of the police are White. These are just a few examples highlighting the need for more people of color working in police departments, especially in cities with large Black populations.

However, while increasing the number of Black police officers is an admirable goal, the recruitment of qualified Black police officers in cities around the country remains exceedingly difficult. Because of lingering concerns in many minority communities of institutionalized racism, Blacks and other racial minorities remain hesitant to work in law enforcement (Sutton, Perry JohnBaptise, \& Williams, 2006). Those racial minorities desiring jobs in law enforcement are also frequently unaware of such opportunities because advertisements for policing jobs and recruitment events are not shared uniformly (Wilson \& Wilson, 2014; Wilson, Wilson, \& Gwann, 2016). This situation undoubtedly excludes viable candidates from applying, which subsequently decreases the overall number of Black applicants that police departments have. 
Thus, there remains a pressing need to develop innovative strategies to ensure that qualified racial minority candidates are reached and afforded the opportunity to apply for jobs in law enforcement (Wilson, Wilson, Luthar, \& Bridges, 2013). One creative way to enhance racial minority recruitment efforts is to use social media platforms such as Facebook, Linkedln, and Instagram, as these have the potential to efficiently disseminate relevant law enforcement job information to specific minority groups (Joos, 2008; Madia, 2011). This targeting approach is not only cost-effective, but it can also significantly increase the pool of qualified minority applicants (Broughton, Foley, Ledermaier, \& Cox, 2013).

A second innovative tool for disseminating law enforcement recruitment information is to use personalized postcards (Linos, 2018). In Chattanooga, Tennessee, which is one of the cities analyzed in this study, correspondence regarding law enforcement job opportunities was sent to applicants via mail. Instead of using a generic salutation, postcards included the name of the intended recipient. A photograph of a current Black police officer was printed on one side of the postcard. On the other side, various messages were printed, such as "I love being part of the police because I feel I can really make a difference in Chattanooga," "Just think what it would mean to you and your community if you became a police officer," and "If you're the kind of person who thrives in challenging environments, you're just the kind of person we're looking for," and these were signed by the Black police officer. An analysis of data showed that persons of color who received the personalized challenge message were four 
times more likely to apply to the police in comparison with minorities who did not receive such messages (Linos, 2018).

A third way to grow the number of qualified Black police officer applicants is to encourage dialogue among students at historically Black colleges and universities (HBCUs), which tend to be ignored by recruiters (Kasperkevic, 2017). Although approximately 300,000 students currently attend HBCUs (Anderson, 2017), these institutions of higher learning are commonly excluded from the recruitment process. Executives often cite budgetary constraints for why they are unable to visit HBCUs (Kasperkevic, 2017). However, if companies were fully aware of the invaluable contributions that HBCU graduates can offer, they would certainly allocate more resources to their recruitment efforts. Professor Marybeth Gasman, a faculty member at the University of Pennsylvania, accurately summarized the $\mathrm{HBCU}$ recruitment problem when she stated that:

"The problem is that many corporations and many Americans for that matter don't know what HBCUs are and are not aware of the contributions these institutions are making to society and to individuals.... Companies need to understand the proven track record that HBCUs have in terms of preparing students with confidence and well-rounded skills that can be used in the workplace" (Hutson, 2010).

Recruitment efforts at HBCUs surely need to increase. Companies such as Apple and Google readily acknowledge their lack of racial diversity and have recently embarked on efforts to partner with HBCUs across the country in the hope of racially diversifying their staff and internship positions (Kasperkevic, 2017). 
Google has even expanded its program to include Hispanic Serving Institutions to build a team that reflects the racial profile of the company's users (Tate, 2018). Both initiatives have proven highly successful as the number of minority applicants and ensuing hires have increased substantially.

There is also no valid reason for why recruitment initiatives at HBCUs cannot be cost-efficient. To take a relevant example: in Greenville, South Carolina, Police Chief Ken Miller implemented a new recruitment program designed specifically to reach educated minority candidates (Rogers, 2018). Prior to the program, Chief Miller publicly acknowledged the lack of racial diversity within his department. His sincere desire to create an agency with a demographic composition that more closely resembled the city motivated him to develop active partnerships with HBCUs. His program enables students from HBCUs who are interested in policing to participate in a day trip, during which they can interact one-on-one with police officers, ask questions, recreate crime scenarios, and participate in a discussion panel. The program is specifically designed to increase racial minority interest and applications. The program has had a dramatic effect on participants by causing many students to change their perception of law enforcement and by motivating others who previously had no interest in law enforcement to apply for job openings.

The use of mentorship has also proven helpful in recruiting Black candidates for law enforcement jobs. Not only does mentorship aid in the eradication of false stereotypes related to law enforcement, it also encourages community-orientated policing. Mentees are more fully prepared for the application and hiring process 
as well. For example, in Savannah, Georgia, which has a police department with a similar racial demographic profile to that of the general population, police officers provide future applicants with the opportunities to participate in mock interviews and provide guidance regarding what to wear, how to fill out the application form, and the skill sets necessary for the position (U.S. Office of Public Affairs, 2017). This initiative has been shown to significantly amplify the number of minority applicants to the police department, which helps to increase the number of Black police officers and the effectiveness of the police department's future minority recruitment efforts.

In addition to increasing the racial diversity of police departments, the use of body-worn cameras (BWCs) by police officers may provide a viable and costeffective means to decrease violent crime by strengthening Black citizens' confidence in the police. Transparency in law enforcement is vital for gaining community support. It is often argued that the use of BWCs by police, which has been endorsed by the American Civil Liberties Union (White, 2014), has the potential to dramatically increase transparency and improve citizens' perceptions of police (Clark, 2013). Because BWCs can provide both visual and auditory accounts of police-citizen encounters, the public can be afforded the opportunity to view and hear the circumstances surrounding any police-citizen encounter. This transparency is advantageous not only because it can help prevent police from abusing their power, but it can also protect police against false citizen claims of abuse and racism that can erode citizens' faith and trust in law enforcement agencies (Harris, 2010; Smykla, Crow, Crichlow, \& Snyder, 2016). 
BWCs have been shown to be effective at improving both police behavior and citizens' perceptions of law enforcement. For example, a recent study by Stolzenberg, D'Alessio, and Flexon (2018) found that the implementation of BWCs in Miami-Dade County resulted in a $34 \%$ decrease in the number of citizen complaints against police officers, a $19 \%$ reduction in the number of cases of physical response to citizen resistance by police officers, and a $74 \%$ drop in the number of civil cases against the Miami-Dade Police Department linked to excessive police use of force. There was also a less dramatic observed decline in the number of internal affair cases, unauthorized force cases, officer injury cases, serious reported crime cases, felony arrests, and civil claims paid by Miami-Dade County for police use of excessive force. Other studies have generated similar results (Farrar, 2013; Jennings, Lynch, \& Fridell, 2015). Not only have BWCs been shown to reduce citizen complaints against the police, but community perceptions of events can be enhanced by allowing public viewing of contentious police-citizen video footage (Culhane \& Schweitzer, 2017). For example, Culhane, Boman \& Schweitzer (2016) found that citizens were more likely to support police in their use of deadly force when audio or visual evidence was made available. Moreover, approval ratings were greatest among citizens who were able to view actual footage of the deadly encounter. Thus, providing citizens with the opportunity to review police-citizen interactions seems to engender a more positive public impression of law enforcement.

Support for BWCs as a means of increasing police transparency also continues to grow in minority communities (Stanley, 2013). In the wake of several 
incidents of fatal shootings by police officers of unarmed Black criminal suspects, Black citizens have generally become much more critical and skeptical of the actions of police generally and have made calls for greater justice, equality, and transparency in the enforcement of criminal laws (Culhane, et al., 2016).

Consequently, it stands to reason that Black citizens should be very supportive of the use of BWCs to help them differentiate between legitimate and illegitimate use of force incidents. Recent research furnishes support for this position. For example, in a national online survey, Sousa, Miethe, and Sakiyama (2017) found that $76 \%$ of Black respondents believed that BWCs are effective at increasing police transparency. In another study, Lawrence, Peterson, and Thompson (2018) found that over $70 \%$ of Black survey respondents in Milwaukee indicated that they supported the Milwaukee Police Department's newly implemented BWC Program. Both studies furnish empirical evidence that the use of BWCs can serve as an effective mechanism for gaining Black citizens' trust in law enforcement.

\section{SUMMARY}

Over 35 years ago, Donald Black (1983) argued that the lack of trust in the police often prevented Blacks and other minority groups from mobilizing law enforcement. The inevitable consequence of this situation is that individuals will employ self-help to mediate personal conflict or retaliate with violence to right a perceived wrong. The multilevel results generated in this study indicate that the racial diversity of a police force plays a significant role in Black citizens' firearm usage in a crime. As the racial diversity of a police department increases in a 
city, the likelihood that a Black citizen will use a firearm in a crime markedly decreases. When one considers that firearms tend to be used by individuals for self-protection when they are afraid and feel vulnerable, the strong negative relationship between the racial diversity of a police department and the likelihood of Black offender using a firearm in a crime gives the impression that Black citizens are less inclined to use firearms because they are confident that the police will protect them in a fair and just manner. In sum, Black citizen faith in the police and the justice system is paramount to attenuate gun crime and violence in urban communities. Without such faith, it is unlikely that violent crime will decrease to any marked degree. Instead, violent crime will likely escalate and further exacerbate police-citizen conflict, grow the prison population, and potentially cause communities of color to become even more disadvantaged. 


\section{LIST OF REFERENCES}

Abt Associates. (1985). Blueprint for the Future of the Uniform Crime Reporting Program. Washington, DC: Bureau of Justice Statistics.

Allen, E., \& Steffensmeier, D. (1989). Youth Underemployment and Property Crime: Differential Effects of Job Availability and Job Quality on Juvenile and Adult Arrest Rates. American Sociological Review, 54(1), 107-123.

Allport, G. W. (1954). The nature of prejudice. Reading, MA: Addison-Wesley.

Anderson, A. L. (2002). Individual and contextual influences on delinquency: The role of the single-parent family. Journal of Criminal Justice, 30(6), 575587.

Anderson, E. (1990). Streetwise: Race. Class, and Change in an Urban Community, Chicago, IL: University of Chicago Press.

Anderson, M. (2017). A look at historically Black colleges and universities as Howard turns 150. Pew Research Center.

Avakame, E. F., Fyfe, J. J., \& McCoy, C. (1999). "Did you call the police? What did they do?" An empirical assessment of Black's theory of mobilization of law. Justice Quarterly, 16(4), 765-792.

Ayres, I., \& Borowsky, J. (2008). A study of racially disparate outcomes in the Los Angeles Police Department. Los Angeles, CA: ACLU of Southern California.

Bailey, W. C. (1984). Poverty, inequality, and city homicide rates: Some not so unexpected findings. Criminology, 22(4), 531-550.

Baldwin, J. (1993). Nobody knows my name: More notes of a native son. New York, NY: Vintage.

Balkwell, J. W. (1983). Metropolitan structure and violent crime: A further 
examination of the Blau and Blau relative deprivation thesis. In annual meeting of the American Society for Criminology, Denver, Colorado.

Balkwell, J. W. (1990). Ethnic inequality and the rate of homicide. Social Forces, 69(1), 53-70.

Banducci, S. A., Donovan, T., \& Karp, J. A. (2004). Minority representation, empowerment, and participation. The Journal of Politics, 66(2), 534-556.

Barlow, D. E., \& Barlow, M. H. (2000). Police in a multicultural society: An American story. Prospect Heights, IL: Waveland.

Barlow, D. E., \& Barlow, M. H. (2002). Racial profiling: A survey of African American police officers. Police Quarterly, 5(3), 334-358.

Barrett, E. J. (1995). The role of public opinion in public administration. The ANNALS of the American Academy of Political and Social Science, 537(1), 150-162.

Barrett, E. J. (1997). Gender and race in the state house: The legislative experience. The Social Science Journal, 34(2), 131-144.

Barton, R. F. (1969). Ifugao Law. Berkeley, CA: University of California Press.

Baumer, E. P., \& Lauritsen, J. L. (2010). Reporting crime to the police, 19732005: a multivariate analysis of long-term trends in the National Crime Survey (NCS) and National Crime Victimization Survey (NCVS). Criminology, 48(1), 131-185.

Beaver, S. J. (1997). Beyond the exclusivity rule: employer's liability for workplace violence. Marq. L. Rev., 81(1), 103.

Becker, G. S. (1974). A theory of social interactions. Journal of Political Economy, 82(6), 1063-1093.

Beeghly, E. (2015). What is a stereotype? What is stereotyping?. Hypatia, 30(4), 675-691.

Bertrand, M., \& Mullainathan, S. (2004). Are Emily and Greg More Employable than Lakisha and Jamal? A Field Experiment on Labor Market Discrimination. American Economic Review, 94(4), 991-1013.

Black, D. J. (1973). The mobilization of law. The Journal of Legal Studies, 2(1), 125-149. 
Black, D. (1976). The Behavior of Law. New York, NY: Academic Press.

Black, D. (1983). Crime as social control. American Sociological Review, 48(1), $34-45$.

Black, D., \& Baumgartner, M. P. (1987). On self-help in modern society. Dialectical Anthropology, 12(1), 33-44.

Blau, J. R., \& Blau, P. M. (1982). The cost of inequality: Metropolitan structure and violent crime. American Sociological Review, 47(1), 114-129.

Blau, P. M., \& Golden, R. M. (1986). Metropolitan structure and criminal violence. Sociological Quarterly, 27(1), 15-26.

Blau, P. M., \& Schwartz, J. (1984). Cross-Cutting Social Circles. Orlando, FL: Academic Press.

Bobo, L., \& Gilliam, F. D. (1990). Race, sociopolitical participation, and Black empowerment. American Political Science Review, 84(2), 377-393.

Bohannan, P. (1960). African Homicide and Suicide. Princeton, NY: Princeton University Press.

Bolton, K. \& Feagin, J. R. (2004). Black in Blue: African-American And Police Officers And Racism. New York, NY: Taylor \& Francis.

Boyd, L. M. (2010). Light blue versus dark blue: Attitudinal differences in qualityof-life policing. Journal of Ethnicity in Criminal Justice, 8(1), 37-48.

Branas, C. C., Han, S., \& Wiebe, D. J. (2016). Alcohol use and firearm violence. Epidemiologic Reviews, 38(1), 32-45.

Breslow, N. E. \& D. G. Clayton. (1993). Approximate inference in generalized linear mixed models. Journal of the American Statistical Association 88(421): 9-25.

Broughton, A., Foley, B., Ledermaier, S., \& Cox, A. (2013). The use of social media in the recruitment process. Institute for Employment Studies, Brighton.

Brown, R. A., \& Frank, J. (2006). Race and officer decision making: Examining differences in arrest outcomes between Black and White officers. Justice Quarterly, 23(1), 96-126.

Brown, R., \& Hewstone, M. (2005). An integrative theory of intergroup 
Contact. Advances in Experimental Social Psychology, 37(37), 255-343.

Browning, S. L., Cullen, F. T., Cao, L., \& Kopache, R. (1994). Race and getting hassled by the police: A research note. Police Stud.: Int'l Rev. Police Dev., 17(1), 1-12.

Browning, S. L., Miller, R. R., \& Spruance, L. M. (2018). Criminal incarceration dividing the ties that bind: Black men and their families. In Impacts of Incarceration on the African American Family (pp. 87-102). New York, NY: Routledge.

Brunson, R. K. (2007). "Police don't like Black people": African-American young men's accumulated police experiences. Criminology \& Public Policy, 6(1), 71-101.

Brunson, R. K., \& Gau, J. M. (2015). Officer race versus macro-level context: A test of competing hypotheses about Black citizens' experiences with and perceptions of Black police officers. Crime \& Delinquency, 61(2), 213-242.

Brunson, R. K., \& Miller, J. (2006). Gender, race, and urban policing: The experience of African American youths. Gender \& Society, 20(4), 531-552.

Bryk, Anthony S., Stephen W. Raudenbush, and Richard T. Congdon, Jr. (1996). HLM: Hierarchical Linear and Nonlinear Modeling with the HLM/2L and $H L M / 3 L$ Programs. Chicago: Scientific Software International, Inc.

Bureau of Justice Statistics. (2013). Law Enforcement Management and Administrative Statistics. (2013). Washington, DC: U.S. Department of Justice. Ann Arbor, MI: Inter-university Consortium for Political and Social Research [distributor], 2015-09-22. https://doi.org/10.3886/ICPSR36164.v2.

Buonanno, P., Fergusson, L., \& Vargas, J. F. (2017). The crime Kuznets curve. Journal of Quantitative Criminology, 33(4), 753-782.

Byrne, J. M., \& Sampson, R. J. (Eds.). (1986). The social ecology of crime (pp. 122). New York, NY: Springer-Verlag.

Cantor, D., \& Lynch, J. P. (2000). Self-report surveys as measures of crime and criminal victimization. Criminal Justice, 4, 85-138.

Cao, L., Frank, J., \& Cullen, F. T. (1996). Race, community context and confidence in the police. American Journal of Police, 15(1), 3-22.

Carr, P. J. (2003). The new parochialism: The implications of the Beltway case 
for arguments concerning informal social control. American Journal of Sociology, 108(6), 1249-1291.

Carr, P. J., Napolitano, L., \& Keating, J. (2007). We never call the cops and here is why: A qualitative examination of legal cynicism in three Philadelphia neighborhoods. Criminology, 45(2), 445-480.

Carroll, L., \& Jackson, P. I. (1983). Inequality, opportunity, and crime rates in central cities. Criminology, 21(2), 178-194.

Centers for Disease Control and Prevention. (2017). Fatal injury reports, national, regional and state, 1981-2016. Atlanta, GA: National Center for Injury Prevention and Control.

Chamlin, M. B. (1989). A macro social analysis of the change in robbery and homicide rates: Controlling for static and dynamic effects. Sociological Focus, 22(4), 275-286.

Chappell, A. T., \& Piquero, A. R. (2004). Applying social learning theory to police misconduct. Deviant Behavior, 25(2), 89-108.

Charbonneau, A., Spencer, K., \& Glaser, J. (2017). Understanding racial disparities in police use of lethal force: Lessons from fatal police-on-police shootings. Journal of Social Issues, 73(4), 744-767.

Circo, G. M., Pizarro, J. M., \& McGarrell, E. F. (2018). Adult and youth involvement in gun-related crime: implications for gun violence prevention interventions. Criminal Justice Policy Review, 29(8), 799-822.

Clark, M. (2013). On-Body Video: Eye Witness or Big Brother?. Police Magazine.

Clear, T. R. (2007). How Mass Incarceration Makes Disadvantaged Neighborhoods Worse. New York, NY: Oxford University Press.

Cobbina, J. E., Owusu-Bempah, A., \& Bender, K. (2016). Perceptions of race, crime, and policing among Ferguson protesters. Journal of Crime and Justice, 39(1), 210-229.

Cohen, L. E., \& Land, K. C. (1987). Age structure and crime: Symmetry versus asymmetry and the projection of crime rates through the 1990s. American Sociological Review, 52(2),170-183.

Coleman, J. W. (1987). Toward an integrated theory of White-collar crime. American Journal of Sociology, 93(2), 406-439. 
Cook, S. W. (1984). Cooperative interaction in multiethnic contexts. In N. Miller, \& M. B. Brewer (Eds.), Groups in Contact: The Psychology of Desegregation (pp. 155-185). Orlando, FL: Academic Press.

Cook, P. J., Kang, S., Braga, A. A., Ludwig, J., \& O’Brien, M. E. (2015). An experimental evaluation of a comprehensive employment-oriented prisoner re-entry program. Journal of Quantitative Criminology, 31(3), 355382.

Cooper, A., \& Smith, E. L. (2017). Homicide trends in the United States, 19802008: annual rates for 2009 and 2010. US Department of Justice Office of Justice Programs Bureau of Justice Statistics.

Culhane, S. E., Boman IV, J. H., \& Schweitzer, K. (2016). Public perceptions of the justifiability of police shootings: The role of body cameras in a pre-and post-Ferguson experiment. Police Quarterly, 19(3), 251-274.

Culhane, S. E., \& Schweitzer, K. (2018). Police shootings and body cameras one year post-Ferguson. Policing and Society, 28(9), 1038-1049.

D'Alessio, S. J., \& Stolzenberg, L. (2003). Race and the probability of arrest. Social Forces, 81(4), 1381-1397.

D’Alessio, S. J., Stolzenberg, L., \& Eitle, D. (2014). "Last hired, first fired": The effect of the unemployment rate on the probability of repeat offending. American Journal of Criminal Justice, 39(1), 77-93.

D'Alessio, S. J., Stolzenberg, L., \& Flexon, J. (2015). Are drug asset forfeiture laws corrupting the police. Weston, WV: Weston Publishing.

Dallaire, D. H. (2007). Incarcerated mothers and fathers: A comparison of risks for children and families. Family Relations, 56(5), 440 - 453.

Danzinger, S. (1976). Explaining urban crime rates. Criminology, 14(2), 291-296.

Dasgupta, N., \& Rivera, L. M. (2006). From automatic antigay prejudice to behavior: The moderating role of conscious beliefs about gender and behavioral control. Journal of Personality and Social Psychology, 91(2), 268-280.

Decker, S. H. (1981). Citizen attitudes toward the police: A review of past findings and suggestions for future policy. Journal of Police Science and Administration, 9(1), 80-87. 
Decker, S. H., Ortiz, N., Spohn, C., \& Hedberg, E. (2015). Criminal stigma, race, and ethnicity: The consequences of imprisonment for employment. Journal of Criminal Justice, 43(2), 108-121.

Devine, P. G. (1989). Stereotypes and prejudice: Their automatic and controlled components. Journal of Personality and Social Psychology, 56(1), 5-18.

Dixon, J. \& Lizotte, A. J. (1987). Gun ownership and the "southern subculture of violence." American Journal of Sociology, 93(2), 383-405.

DuRant, R. H., Cadenhead, C., Pendergrast, R. A., Slavens, G., \& Linder, C. W. (1994). Factors associated with the use of violence among urban Black adolescents. American Journal of Public Health, 84(4), 612-617.

Durkheim, E. (1897). 1951. Suicide: A study in sociology. New York, NY: Routledge.

Duster, T. (1987). Crime, youth unemployment, and the Black urban underclass. Crime \& Delinquency, 33(2), 300-316.

Easton, D. (1975). A re-assessment of the concept of political support. British Journal of Political Science, 5(4), 435-457.

Fagan, J., \& Tyler, T. R. (2005). Legal socialization of children and adolescents. Social Justice Research, 18(3), 217-241.

Farrar, T. (2013). Self-awareness to being watched and socially-desirable behavior: a field experiment on the effect of body-worn cameras on police use-of-force. Police Foundation.

Farrington, D. P., \& Murray, J. (Eds.). (2013). Labeling theory: Empirical tests (Vol. 1). New Brunswick, NJ: Transaction Publishers.

Feagin, J. R., \& Sikes, M. P. (1994). Living with racism: The Black middle-class experience. North Palm Beach, FL: Beacon Press.

Federal Bureau of Investigation. (2000). National Incident-Based Reporting System, Volume 1: Data Collection Guidelines. Washington, DC: U.S. Government Printing Office.

Federal Bureau of Investigation. (2015). National Incident-Based Reporting System. Extract Files. Ann Arbor, MI: Inter-university Consortium for Political and Social Research [distributor], 2018-10-05. https://doi.org/10.3886/ICPSR36851.v2. 
Federal Bureau of Investigation (2018). Crime in the United States, 2017. Retrieved from: https://ucr.fbi.gov/crime-in-the-u.s/2017/crime-in-the-u.s.2017/topic-pages/tables/table-43.

Felson, M., \& Cohen, L. E. (1980). Human ecology and crime: A routine activity approach. Human Ecology, 8(4), 389-406.

Fenno, R. F. (1978). Home style: House members in their districts. New York, NY: HarperCollins.

Fine, A., Simmons, C., Miltimore, S., Steinberg, L., Frick, P. J., \& Cauffman, E. (2018). The school experiences of male adolescent offenders: Implications for academic performance and recidivism. Crime \& Delinquency, 64(10), 1326-1350.

Fiske, S. (2010). Are we born racist? Greater good, summer, 14-17. In J. Marsh, R. Mendoza-Denton, \& J. Adam Smith (Eds.), Are we born racist? New Insights from Neuroscience and Positive Psychology (pp. 7-16). Boston, MA: Beacon Press.

Flanagan, T. J., \& Vaughn, M. S. (1996). Public opinion about police abuse of force. Police Violence: Understanding and Controlling Police Abuse of Force, 30(5), 397-408.

Floyd et al v. The City of New York, Opinion and Order, 08 Civ. 1034 (SAS). U.S District Court for the Southern District of New York. August 12, 2013.

Freeman, R. B. (1996). Why do so many young American men commit crimes and what might we do about it. Journal of Economic Perspectives, 10(1), $25-42$.

Fridell, L., \& Lim, H. (2016). Assessing the racial aspects of police force using the implicit-and counter-bias perspectives. Journal of Criminal Justice, 44(1), 36-48.

Fowler, K. A., Dahlberg, L. L., Haileyesus, T., Gutierrez, C., \& Bacon, S. (2017). Childhood firearm injuries in the United States. Pediatrics, 140(1), 1-11.

Futterman, C. B., Hunt, C., \& Kalven, J. (2017). Youth/Police Encounters on Chicago's South Side: Acknowledging the Realities. University of Chicago Legal Forum, 51(4), 1079-1178.

Gabrielson, R., Jones, R. G., \& Sagara, E. (2014). Deadly force, in Black and White. ProPublica. Retrieved from: https://www.propublica.org/article/deadly-force-in-Black-and-White. 
Galster, G., \& Santiago, A. (2017). Neighbourhood ethnic composition and outcomes for low-income Latino and African American children. Urban Studies, 54(2), 482-500.

Garland, D. (2012). The culture of control: Crime and social order in contemporary society. Chicago, IL: University of Chicago Press.

Garofalo, J. (1977). Public opinion about crime: The attitudes of victims and nonvictims in selected cities (Vol. 1). US Department of Justice, Law Enforcement Assistance Administration, National Criminal Justice Information and Statistics Service.

Gau, J. M., \& Brunson, R. K. (2015). Procedural injustice, lost legitimacy, and self-help: Young males' adaptations to perceived unfairness in urban policing tactics. Journal of Contemporary Criminal Justice, 31(2), 132-150.

Gay, C. (2001). The effect of Black congressional representation on political participation. American Political Science Review, 95(3), 589-602.

Gibbs, J. T. (1988). Young, Black, and male in America: An endangered species. Dover, MA: Auburn House Publishing Company.

Gibson, C. L., Walker, S., Jennings, W. G., \& Miller, J. (2010). The impact of traffic stops on calling the police for help. Criminal Justice Policy Review, 21(2), 139-159.

Gill, C., Weisburd, D., Telep, C. W., Vitter, Z., \& Bennett, T. (2014). Communityoriented policing to reduce crime, disorder and fear and increase satisfaction and legitimacy among citizens: A systematic review. Journal of Experimental Criminology, 10(4), 399-428.

Giwa, S. (2018). Community policing in racialized communities: A potential role $f$ or police social work. Journal of Human Behavior in the Social Environment, 28(6), 710-730.

Glaze, L. E. \& Maruschak, L. M. (2008). Parents in Prison and their Minor Children. Washington, DC: U.S. Bureau of Justice Statistics.

Godsil, R. D., Tropp, L. R., Goff, P. A., \& Powell, J. A. (2014). The Science of equality, Volume 1: Addressing implicit bias, racial anxiety, and stereotype threat in education and health care. Perception Institute (online).

Goldstein, P. J. (1985). The drugs/violence nexus: A tripartite conceptual framework. Journal of Drug Issues, 15(4), 493-506. 
Goldstein, H. (1987). Toward community-oriented policing: Potential, basic requirements, \& threshold questions. Crime \& Delinquency, 33(1), 6-30.

Gould, E. D., Weinberg, B. A., \& Mustard, D. B. (2002). Crime rates and local labor market opportunities in the United States: 1979-1997. Review of Economics and Statistics, 84(1), 45-61.

Grabosky, P. N. (1992). Law enforcement and the citizen: Non-governmental participants in crime prevention and control. Policing and Society: An International Journal, 2(4), 249-271.

Gross, K. N. (2015). African American women, mass incarceration, and the politics of protection. Journal of American History, 102(1), 25-33.

Gurin, P., Hatchett, S., \& Jackson, J. S. (1990). Hope and independence: Blacks' response to electoral and party politics. New York, NY: Russell Sage Foundation.

Gustafson, J. (2013). Diversity in municipal police agencies: A national examination of minority hiring and promotion. Policing: an International Journal of Police Strategies \& Management, 36(4), 719-736.

Haas, N. E., de Keijser, J. W., \& Bruinsma, G. J. (2014). Public support for vigilantism, confidence in police and police responsiveness. Policing and Society, 24(2), 224-241.

Hagan, J., \& Albonetti, C. (1982). Race, class, and the perception of criminal injustice in America. American Journal of Sociology, 88(2), 329-355.

Haider-Markel, D. P., Joslyn, M. R., \& Kniss, C. J. (2000). Minority group interests and political representation: Gay elected officials in the policy process. The Journal of Politics, 62(2), 568-577.

Hamilton, D., Darity Jr, W., Price, A. E., Sridharan, V., \& Tippett, R. (2015). Umbrellas don't make it rain: Why studying and working hard isn't enough for Black Americans. New York, NY: The New School.

Harer, M. D., \& Steffensmeier, D. (1992). The differing effects of economic inequality on Black and White rates of violence. Social Forces, 70(4), 1035-1054.

Harper, S. R. (2008). Realizing the intended outcomes of Brown: High-achieving African American male undergraduates and social capital. American Behavioral Scientist, 51(7), 1030-1053. 
Harper, S. R., Patton, L. D., \& Wooden, O. S. (2009). Access and equity for African American students in higher education: A critical race historical analysis of policy efforts. The Journal of Higher Education, 80(4), 389-414.

Harris, D. A. (2010). Picture this: Body-worn video devices (heads cams) as tools for ensuring fourth amendment compliance by police. Tex. Tech L. Rev., 43(2010), 357-372.

Herbert, B. (2010). Jim Crow Policing. The New York Times, 1.

Herbert, S. (1998). Police subculture reconsidered. Criminology, 36(2), 343-370.

Herring, A. L., \& Potter, C. (2018). A Year After Pittsburg Eased Residency Rule, One-Fifth of Police Force Lives Outside City. Pittsburg NPR News Station. Retrieved from: https://www.wesa.fm/post/year-after-pittsburgh-easedresidency-rule-one-fifth-police-force-lives-outside-city.

Hindelang, M. J. (1974). Public opinion regarding crime, criminal justice, and related topics. Journal of Research in Crime and Delinquency, 11(2), 101116.

Hindelang, M. J., Hirschi, T., \& Weis, J. G. (1981). Measuring delinquency. Thousand Oaks, CA: Sage Publishing.

Hirschi, Travis \& Michael Gottfredson. (1983). Age and the explanation of crime. American Journal of Sociology, 89(3), 552-584.

Hobbes, T. (1994). Leviathan (1651), ed. Herbert Schneider (Indianapolis, IN: Bobbs-Merrill, 1958), 109.

Hoebel, E. Adamson 1954 The Law of Primitive Man: A Study in Comparative Legal Dynamics. Cambridge, MA: Harvard University Press.

Holzer, H. J., Offher, P., \& Sorensen, E. (2005). Declining Employment among Young Black Less-Educated Men: The Role of Incarceration and Child Support. Journal of Policy Analysis and Management, 24(2), 329-350.

Holzer, H. J., Raphael, S., \& Stoll, M. A. (2007). The effect of an applicant's criminal history on employer hiring decisions and screening practices: Evidence from Los Angeles. Barriers to Reentry, 4(15), 117-150.

Hong, S. (2015). Ethnic diversity in public organizations and public service performance: Empirical investigation. In Academy of Management Proceedings. Briarcliff Manor, NY: Academy of Management. 
Hong, S. (2017). Does increasing ethnic representativeness reduce police misconduct?. Public Administration Review, 77(2), 195-205.

Huang, W., \& Vaughn, M. S. (1996). Support and confidence: Public attitudes toward the police. Americans view crime and justice: A National Public Opinion Survey. Thousand Oaks, CA: Sage Publishing.

Hurst, Y. G., Frank, J., \& Lee Browning, S. (2000). The attitudes of juveniles toward the police: A comparison of Black and White youth. Policing: An International Journal of Police Strategies \& Management, 23(1), 37-53.

Hutson, B. (2010, November 2). From the Classroom to Employment: A Look at Recruiting at HBCUs. Retrieved from:

https://madamenoire.com/105505/from-the-classroom-to-employment-alook-at-recruiting-at-hbcus/.

Ismaili, K. (2015). US criminal justice policy: A contemporary reader. Burlington, MA: Jones \& Bartlett Publishers.

Jackson, J., Huq, A. Z., Bradford, B., \& Tyler, T. R. (2013). Monopolizing force? Police legitimacy and public attitudes toward the acceptability of violence. Psychology, Public Policy, and Law, 19(4), 479-497.

James, L., Klinger, D., \& Vila, B. (2014). Racial and ethnic bias in decisions to shoot seen through a stronger lens: Experimental results from high-fidelity laboratory simulations. Journal of Experimental Criminology, 10(3), 323340.

Jacobs, D., \& Richardson, A. M. (2008). Economic inequality and homicide in the developed nations from 1975 to 1995. Homicide Studies, 12(1), 28-45.

Jennings, W. G., Lynch, M. D., \& Fridell, L. A. (2015). Evaluating the impact of police officer body-worn cameras (BWCs) on response-to-resistance and serious external complaints: Evidence from the Orlando police department (OPD) experience utilizing a randomized controlled experiment. Journal of Criminal Justice, 43(6), 480-486.

Jonson, C. L., \& Cullen, F. T. (2015). Prisoner reentry programs. Crime and Justice, 44(1), 517-575.

Joos, J. G. (2008). Social media: New frontiers in hiring and recruiting. Employment Relations Today, 35(1), 51-59.

Junger-Tas, J., \& Marshall, I. H. (1999). The self-report methodology in crime 
research. Crime and Justice, 25(1), 291-367.

Kalev, A. (2009). Cracking the glass cages? Restructuring and ascriptive inequality at work. American Journal of Sociology, 114(6), 1591-1643. Karmen, A. (1990). Crime victims: an introduction to criminology. Belmont, CA: Wadsworth.

Kasperkevic, J. (2017). Recruiters often overlook historically Black colleges and universities. Marketplace.org. Retrieved from:

https://www.marketplace.org/2017/08/03/recruiters-often-overlookhistorically-Black-colleges/.

Katz, P. A., \& Katz, P. A. (1976). Racism and social science: Towards a new commitment. Elmsford, NY: Pergamon Press.

Kelling, G. (1988). Police \& Communities: The Quiet Revolution. Washington, DC: U.S. Department of Justice.

Kelly, M. (2000). Inequality and crime. Review of Economics and Statistics, 82(4), 530-539.

Kelly, R. M., \& Farber, M. G. (1974). Identifying responsive inner-city policemen. Journal of Applied Psychology, 59(3), 259.

Kennedy, R. (1997). Race, Crime, and the Law. New York, NY: Pantheon Books.

Kirk, D. S., \& Matsuda, M. (2011). Legal cynicism, collective efficacy, and the ecology of arrest. Criminology, 49(2), 443-472.

Kirk, D. S., \& Papachristos, A. V. (2011). Cultural mechanisms and the persistence of neighborhood violence. American Journal of Sociology, 116(4), 1190-1233.

Kleck, G., \& Gertz, M. (1998). Carrying guns for protection: results from the National Self-Defense Survey. Journal of Research in Crime and Delinquency, 35(2), 193-224.

Klinger, D. A. (1997). Negotiating order in patrol work: An ecological theory of police response to deviance. Criminology, 35(2), 277-306.

Krivo, L. J., Peterson, R. D., \& Kuhl, D. C. (2009). Segregation, racial structure, and neighborhood violent crime. American Journal of Sociology, 114(6), 1765-1802.

Lab, S. P., \& Allen, R. B. (1984). Self-report and official measures: A further 
examination of the validity issue. Journal of Criminal Justice, 12(5), 445455.

LaFree, G., Baumer, E. P., \& O'Brien, R. (2010). Still separate and unequal? A city-level analysis of the Black-White gap in homicide arrests since 1960. American Sociological Review, 75(1), 75-100.

Langness, L. L. (1972). Violence in the New Guinea Highlands. In Collective Violence, In J. F. Short \& M. E. Wolfgang (Eds.), Collective Violence (pp. 171-185). Chicago, IL: Aldine Atherton.

Lauritsen, J. L., \& Heimer, K. (2008). The gender gap in violent victimization, 1973-2004. Journal of Quantitative Criminology, 24(2), 125-147.

Lauritsen, J. L., Heimer, K., \& Lynch, J. P. (2009). Trends in the gender gap in violent offending: New evidence from the National Crime Victimization Survey. Criminology, 47(2), 361-399.

Lawrence, D. S., Peterson, B. E., \& Thompson, P. S. (2018). Community Views of Milwaukee's Police Body-Worn Camera Program. Washington DC: Urban Institute.

Lee, A. M., \& Humphrey, N. D. (1968). Race Riot, Detroit. New York, NY: Octagon Books.

Lee, J. M., Steinberg, L., Piquero, A. R., \& Knight, G. P. (2011). Identity-linked perceptions of the police among African American juvenile offenders: A developmental perspective. Journal of Youth and Adolescence, 40(1), 2337.

Lee, M. R., \& Bankston, W. (1999). Political structure, economic inequality, and homicide: A cross-national analysis. Deviant Behavior: An Interdisciplinary Journal, 20(1), 27-55.

Lee, M. R., Maume, M. O., \& Ousey, G. C. (2003). Social isolation and lethal violence across the metro/nonmetro divide: The effects of socioeconomic disadvantage and poverty concentration on homicide. Rural Sociology, 68(1), 107-131.

Legewie, J., \& Fagan, J. (2016). Group threat, police officer diversity and the deadly use of police force. Columbia Public Law Research Paper, (14512). 
Lemieux, F. (2014). Effect of gun culture and firearm laws on gun violence and mass shootings in the United States: A multi-level quantitative analysis. International Journal of Criminal Justice Sciences, 9(1) 74-93.

Light, M. T., \& Ulmer, J. T. (2016). Explaining the gaps in White, Black, and Hispanic violence since 1990: Accounting for immigration, incarceration, and inequality. American Sociological Review, 81(2), 290-315.

Linos, E. (2018). Simple Changes to Job Ads Can Help Recruit More Police Officers of Color. Harvard Business Review. Retrieved from: https://hbr.org/2018/04/simple-changes-to-job-ads-can-help-recruit-morepolice-officers-of-color.

Lizotte, A. J., Bordua, D. J., \& White, C. S. (1981). Firearms ownership for sport and protection: Two not so divergent models. American Sociological Review, 46(4), 499-503.

Lochner, L., \& Moretti, E. (2004). The effect of education on crime: Evidence from prison inmates, arrests, and self-reports. American Economic Review, 94(1), 155-189.

Logan, J. R., \& Messner, S. F. (1987). Racial residential segregation and suburban violent crime. Social Science Quarterly, 68(3), 510-527.

Lundman, R. J., \& Kaufman, R. L. (2003). Driving while Black: Effects of race, ethnicity, and gender on citizen self-reports of traffic stops and police actions. Criminology, 41(1), 195-220.

Lyon, A. D. (2011). Race Bias and the Importance of Consciousness for Criminal Defense Attorneys. Seattle UL Rev., 35(3), 755-768.

MacDonald, J., \& Stokes, R. J. (2006). Race, Social Capital, and Trust in the Police. Urban Affairs Review, 41(3), 358-375.

MacDonald, J., Stokes, R. J., Ridgeway, G., \& Riley, K. J. (2007). Race, neighbourhood context and perceptions of injustice by the police in Cincinnati. Urban Studies, 44(13), 2567-2585.

Mansbridge, J. (1999). Should Blacks represent Blacks and women represent women? A contingent" yes". The Journal of Politics, 61(3), 628-657.

Madia, S. A. (2011). Best practices for using social media as a recruitment strategy. Strategic HR Review, 10(6), 19-24. 
Massoglia, M., Firebaugh, G., \& Warner, C. (2013). Racial variation in the effect of incarceration on neighborhood attainment. American Sociological Review, 78(1), 142-165.

McDowall, D., \& Loftin, C. (1983). Collective security and the demand for legal handguns. American Journal of Sociology, 88(6), 1146-1161.

Merton, R. K. (1957). Social theory and social structure: Toward the codification of theory and research. New York, NY: Free Press.

Merton, R. K. (1959). Social conformity, deviation, and opportunity structures: A comment on the contributions of Dubin and Cloward. American Sociological Review, 59(24), 177-189.

Messner, S. F. (1983). Regional differences in the economic correlates of the urban homicide rate: Some evidence on the importance of cultural context. Criminology, 21(4), 477-488.

Messner, S. F. (1989). Economic discrimination and societal homicide rates: Further evidence on the cost of inequality. American Sociological Review, 54(4), 597-611.

Messner, S. F., \& Golden, R. M. (1992). Racial inequality and racially disaggregated homicide rates: An assessment of alternative theoretical explanations. Criminology, 30(3), 421-448.

Moore, M. H. (1992). Problem-solving and community policing. Crime and Justice, 15(1992), 99-158.

Morgan, R. E., \& Kena, G. (2017). Criminal victimization, 2016. Bureau of Justice Statistics. NCJ, 251150.

Morin, R., \& Stepler, R. (2016). The racial confidence gap in police performance. Pew Research Center, 29.

Moskos, P. (2008). Cop in the hood: My year policing Baltimore's eastern district. Princeton University Press.

Murphy, D. W., \& Worrall, J. L. (1999). Residency requirements and public perceptions of the police in large municipalities. Policing: An International Journal of Police Strategies \& Management, 22(3), 327-342.

Nash, J. (1967). Death as a way of life: The increasing resort to homicide in a Maya Indian community. American Anthropologist, 69(5), 455-470. 
Needels, K. (1996). Go Directly to Jail and Do Not Collect? A Long-Term Study of Recidivism, Employment, and Earnings Patterns among Prison Releasees. Journal of Research in Crime and Delinquency, 33(4), 471496.

Nordin, M., \& Almén, D. (2017). Long-term unemployment and violent crime. Empirical Economics, 52(1), 1-29.

Nowacki, J. S., \& Spencer, T. (2019). Police discretion, organizational characteristics, and traffic stops: An analysis of racial disparity in I Illinois. International Journal of Police Science \& Management, 21(1), 416.

Ostrom, E., \& Whitaker, G. P. (1974). Community control and governmental responsiveness: the case of police in Black neighborhoods. Improving the Quality of Urban Management, 10(4), 303-34.

Pager, D. (2003). The Mark of a Criminal Record. American Journal of Sociology, 108(5), 937-975.

Pager, D. (2007). Marked: Race, Crime, and Finding Work in an Era of Mass Incarceration. Chicago, IL: University of Chicago Press.

Pager, D., \& Quillian, L. (2005). Walking the Talk? What Employers Say versus What They Do. American Sociological Review, 70(3), 355-380.

Pager, D., Western, B., \& Sugie, N. (2009). Sequencing disadvantage: Barriers to employment facing young Black and White men with criminal records. The ANNALS of the American Academy of Political and Social Science, 623(1), 195-213.

Parker, K. F., \& McCall, P. L. (1999). Structural conditions and racial homicide patterns: A look at the multiple disadvantages in urban areas. Criminology, 37(3), 447-478.

Patterson, E. B. (1991). Poverty, income inequality, and community crime rates. Criminology, 29(4), 755-776.

Peffley, M., \& Hurwitz, J. (2010). Justice in America: The separate realities of Blacks and Whites. New York, NY: Cambridge University Press.

Perkins, C. A. (1997). Age patterns of victims of serious violent crime (pp. 1-7). US Department of Justice, Office of Justice Programs, Bureau of Justice Statistics. 
Peterson, R. D., \& Krivo, L. J. (1993). Racial segregation and Black urban homicide. Social Forces, 71(4), 1001-1026.

Peterson, R. D., Krivo, L. J., \& Harris, M. A. (2000). Disadvantage and neighborhood violent crime: Do local institutions matter?. Journal of Research in Crime and Delinquency, 37(1), 31-63.

Pettit, B. (2012). Invisible men: Mass incarceration and the myth of Black progress. New York, NY: Russell Sage Foundation.

Pettigrew, T. F., Tropp, L. R., Wagner, U., \& Christ, O. (2011). Recent advances in intergroup contact theory. International Journal of Intercultural Relations, 35(3), 271-280.

Pew Research Center (2015). Parenting in America: Outlook, worries, aspirations are strongly liked to financial situation. Retrieved from http://assets.pewresearch.org/wp-content/uploads/sites/3/2015/12/201512-17_parenting-in-america_FINAL.pdf.

Preston, M. B. (1978). Black Elected Officials and Public Policy: Symbolic or Substantive Representation?. Policy Studies Journal, 7(2), 196-201.

Reaves, B. A. (2010). Local police departments, 2007. Washington, DC: Bureau of Justice Statistics.

Reaves, B. A. (2015). Local police departments, 2013: Personnel, policies, and practices. Washington, DC: Bureau of Justice Statistics.

Reich, M., Gordon, D. M., \& Edwards, R. C. (1973). Dual Labor Markets: A Theory of Labor Market Segmentation. American Economic Review, 63(2), 359-365.

Reisig, M. D., \& Giacomazzi, A. L. (1998). Citizen perceptions of community policing: are attitudes toward police important?. Policing: An International Journal of Police Strategies \& Management, 21(3), 547-561.

Reisig, M. D., \& Lloyd, C. (2009). Procedural justice, police legitimacy, and helping the police fight crime: Results from a survey of Jamaican adolescents. Police Quarterly, 12(1), 42-62.

Reiss Jr, A. J., \& Bordua, D. J. (1967). Organization and environment: A perspective on the police. The Police: Six Sociological Essays, edited by David J. Bordua. New York, NY: Wiley.

Richardson, L. S. (2010). Arrest Efficiency and the Fourth Amendment. Minn. L. 
Rev., 95(6), 2035-2098.

Ringel, C. (1995). Criminal victimization 1996. Washington, DC: US Department of Justice, Office of Justice Programs, Bureau of Justice Statistics.

Rogers, E. (2018, April 23). Greenville PD partners with HBCUs to increase diversity. Retrieved from: https://www.wspa.com/news/greenville-pdpartners-with-hbcus-to-increase-diversity/1136106511.

Rogers, M. L., \& Pridemore, W. A. (2013). The effect of poverty and social protection on national homicide rates: Direct and moderating effects. Social Science Research, 42(3), 584-595.

Rosenbaum, D. P., Schuck, A. M., Costello, S. K., Hawkins, D. F., \& Ring, M. K. (2005). Attitudes toward the police: The effects of direct and vicarious experience. Police Quarterly, 8(3), 343-365.

Ruiz, D. S., \& Kopak, A. (2014). The consequences of parental incarceration for African American mothers, children, and grandparent caregivers. Journal of Pan African Studies, 7(6), 9-25.

Sameroff, A.J., Bartko, W.T., Baldwin, A., Baldwin, C., \& Seifer, R. (1998). Family and social influences on the development of child competence. In C.

Feiring \& M. Lewis (Eds.), Families, Risk and Competence (pp. 161-185). Mahwah, NJ: Lawrence Erlbaum.

Sampson, R. J. (1983). Structural density and criminal victimization. Criminology, 21(2), 276-293.

Sampson, R. J. (1985). Race and criminal violence: A demographically disaggregated analysis of urban homicide. Crime \& Delinquency, 31(1), 47-82.

Sampson, R. J. (1986). Neighborhood family structure and the risk of personal victimization. The Social Ecology of Crime (pg. 25-46). New York, NY: Springer-Verlag.

Sampson, R. J. (1987). Urban Black violence: The effect of male joblessness and family disruption. American Journal of Sociology, 93(2), 348-382.

Sampson, R. J., \& Bartusch, D. J. (1998). Legal cynicism and (subcultural) tolerance of deviance: the neighborhood context of racial difference. Law \& Soc'y Rev., 32(4), 777-804. 
Sampson, R. J., \& Groves, W. B. (1989). Community structure and crime:

Testing social-disorganization theory. American Journal of Sociology, 94(4), 774-802.

Sampson, R. J., Morenoff, J. D., \& Raudenbush, S. (2005). Social anatomy of racial and ethnic disparities in violence. American Journal of Public Health, 95(2), 224-232.

Sampson, R. J., Wilson, W. J., \& Katz, H. (2018). Reassessing "toward a theory of race, crime, and urban inequality": Enduring and New Challenges in $21^{\text {st }}$ Century America. Du Bois Review: Social Science Research on Race, 15(1), 13-34.

Savitz, L. (1970). The dimensions of police loyalty. American Behavioral Scientist, 13(5-6), 693-704.

Scherer, N., \& Curry, B. (2010). Does descriptive race representation enhance institutional legitimacy? The case of the US courts. The Journal of Politics, 72(1), 90-104.

Schneider, C. L. (2014). Police power and race riots: Urban unrest in Paris and New York. University of Pennsylvania Press.

Schuman, H., \& Johnson, M. P. (1976). Attitudes and behavior. Annual Review of Sociology, 2(1), 161-207.

Shihadeh, E. S., \& Steffensmeier, D. J. (1994). Economic inequality, family disruption, and urban Black violence: Cities as units of stratification and social control. Social Forces, 73(2), 729-751.

Shusta, R. M., Levine, D. R., Harris, P. R., \& Wong, H. Z. (1995). Multicultural law enforcement. Strategies for Peacekeeping in a Diverse Society. New York, NY: Pearson.

Siegel, M., Negussie, Y., Vanture, S., Pleskunas, J., Ross, C. S., \& King III, C. (2014). The relationship between gun ownership and stranger and nonstranger firearm homicide rates in the United States, 19812010. American Journal of Public Health, 104(10), 1912-1919.

Silver, N. (2014). Most police don't live in the cities they serve. Fivethirtyeight. Com. Retrieved from: https://fivethirtyeight.com/features/most-police-dontlive-in-the-cities-they-serve/.

Skogan, W. G. (1979). Citizen satisfaction with police services. Policy Studies Journal, 7(1) 469-479. 
Skolnick, J. H. (2011). Justice without Trial: Law enforcement in Democratic Society. New Orleans, LA: Quid Pro Books.

Smith, D. (1987). Research, the community and the police. Policing and the Community, London: Policy Studies Institute.

Smith, D. C. (1980). Police Attitudes and Performance: The Impact of Residency. Urban Affairs Quarterly, 15(3), 317-334.

Smith, D. A., \& Uchida, C. D. (1988). The social organization of self-help: A study of defensive weapon ownership. American Sociological Review, 53(1), 94102.

Smith, D. A., \& Jarjoura, G. R. (1989). Household characteristics, neighborhood composition and victimization risk. Social Forces, 68(2), 621-640.

Smith, E. L., \& Cooper, A. D. (2013). Homicide in the US known to law enforcement, 2011. Washington, DC: US Department of Justice, Office of Justice Programs, Bureau of Justice Statistics.

Smith, M. R., \& Alpert, G. P. (2007). Explaining police bias: A theory of social conditioning and illusory correlation. Criminal Justice and Behavior, 34(10), 1262-1283.

Smith-Ruiz, D. (2008). African American grandmothers providing extensive care to their grandchildren: Socio-demographic and health determinants of life satisfaction. J. Soc. \& Soc. Welfare, 35(4), 29-52.

Smykla, J. O., Crow, M. S., Crichlow, V. J., \& Snyder, J. A. (2016). Police bodyworn cameras: Perceptions of law enforcement leadership. American Journal of Criminal Justice, 41(3), 424-443.

Sousa, W. H., Miethe, T. D., \& Sakiyama, M. (2017). Inconsistencies in public opinion of body-worn cameras on police: Transparency, trust, and improved police-citizen relationships. Policing: A Journal of policy and Practice, 12(1), 100-108.

South, S. J., \& Felson, R. B. (1990). The racial patterning of rape. Social Forces, 69(1), 71-93.

Stanley, J. (2013). Police body-mounted cameras: With right policies in place, a win for all. New York: ACLU, 2.

Steele, C. M. (1997). A threat in the air: How stereotypes shape intellectual 
identity and performance. American Psychologist, 52(6), 613-629.

Stewart, E. A., Baumer, E. P., Brunson, R. K., \& Simons, R. L. (2009).

Neighborhood racial context and perceptions of police-based racial discrimination among Black youth. Criminology, 47(3), 847-887.

Stolzenberg, L., D'Alessio, S., \& Flexon, J.. (2018). Eyes on the Street: Police Use of Body-Worn Cameras in Miami-Dade County. Weston, WV: Weston Publishing.

Stone, C., Carter, Z., Belfiore, T., Bully-Cummings, E. M., Daughtry, R. D. H., Farrell, M. J., ... \& Hewitt, D. T. (2010). Reducing Inherent Danger: Report of the Task Force on Police-on-Police Shootings.

Sun, I. Y., \& Payne, B. K. (2004). Racial differences in resolving conflicts: A comparison between Black and White police officers. Crime \& Delinquency, 50(4), 516-541.

Sun, I. Y., Sung, H. E., \& Chu, D. C. (2007). Collateral gains from the military? A cross-national analysis of the armed forces crime relationship. International Journal of Offender Therapy and Comparative Criminology, 51(5), 599-614.

Sutton, M., Perry, B., John-Baptiste, C., \& Williams, G. (2006). Black and Asian police officers and support staff: Prejudice, identity, agency and social cohesion. Internet Journal of Criminology.

Tankebe, J. (2009). Self-help, policing, and procedural justice: Ghanaian vigilantism and the rule of law. Law \& Society Review, 43(2), 245-270.

Tate, E. (2018, Sep 19). Google, Expanding on HBCU Pilot, Launches 'Tech Exchange' to Boost Diversity in Industry. Retrieved from: https://www.edsurge.com/news/2018-09-19-google-expanding-on-hbcupilot-launches-tech-exchange-to-boost-diversity-in-industry.

Taylor, T. J., Turner, K. B., Esbensen, F. A., \& Winfree Jr, L. T. (2001). Coppin'an attitude: Attitudinal differences among juveniles toward police. Journal of Criminal Justice, 29(4), 295-305.

Terrill, W., \& Reisig, M. D. (2003). Neighborhood context and police use of force. Journal of Research in Crime and Delinquency, 40(3), 291-321.

Theobald, N. A., \& Haider-Markel, D. P. (2008). Race, bureaucracy, and symbolic representation: Interactions between citizens and police. Journal of Public Administration Research and Theory, 19(2), 409-426. 
Troxel, W. M., Lee, L., Hall, M., \& Matthews, K. A. (2014). Single-parent family structure and sleep problems in Black and White adolescents. Sleep Medicine, 15(2), 255-261.

Tyler, T. R. (1997). The psychology of legitimacy: A relational perspective on voluntary deference to authorities. Personality and Social Psychology Review, 1(4), 323-345.

Tyler, T. R. (2005). Policing in Black and White: Ethnic group differences in trust and confidence in the police. Police Quarterly, 8(3), 322-342.

U.S. Census Bureau (2017), Population Estimates Program. Retrieved from https://www.census.gov/quickfacts/fact/table/US/PST045217.

U.S. Office of Public Affairs (2017). Promoting Promising Practices to Advance Diversity in Law Enforcement. Retrieved from:

https://www.justice.gov/archives/opa/blog/promoting-promising-practicesadvance-diversity-law-enforcement.

Vacha, E. F., \& McLaughlin, T. F. (2004). Risky firearms behavior in low-income families of elementary school children: The impact of poverty, fear of crime, and crime victimization on keeping and storing firearms. Journal of Family Violence, 19(3), 175-184.

Violence Policy Center. (2018). Black Homicide Victimization in the United States: An Analysis of 2015 Homicide Data. Retrieved from: http://vpc.org/studies/Blackhomicide18.pdf.

Viscusi, W. K. (1986). The risks and rewards of criminal activity: a comprehensive test of criminal deterrence. Journal of Labor Economics, 4(3, Part 1), 317-340.

Voci, A., \& Hewstone, M. (2003). Intergroup contact and prejudice toward immigrants in Italy: The mediational role of anxiety and the moderational role of group salience. Group Processes \& Intergroup Relations, 6(1), 3754.

Walker, S. (1998). Popular Justice: A History of American Criminal Justice. New York, NY: Oxford Univ. Press.

Watkins, A. M., \& Melde, C. (2018). Gangs, gender, and involvement in crime, victimization, and exposure to violence. Journal of Criminal Justice, 57(July-August), 11-25. 
Webb, V. J., \& Marshall, C. E. (1995). The relative importance of race and ethnicity on citizen attitudes toward the police. American Journal of Police, 14(2), 45-66.

Weisburd, D., Greenspan, R., Hamilton, E. E., Williams, H., \& Bryant, K. A. (2000). Police attitudes toward abuse of authority: Findings from a national study. Washington, DC: US Department of Justice, Office of Justice Programs, National Institute of Justice.

Weitzer, R. (2000a). Racialized policing: Residents' perceptions in three neighborhoods. Law and Society Review, 34(1), 129-155.

Weitzer, R. (2000b). White, Black, or blue cops? Race and citizen assessments of police officers. Journal of Criminal Justice, 28(4), 313-324.

Weitzer, R. (2002). Incidents of police misconduct and public opinion. Journal of Criminal Justice, 30(5), 397-408.

Weitzer, R. (2015). American policing under fire: Misconduct and reform. Society, 52(5), 475-480.

Weitzer, R., \& Tuch, S. A. (1999). Race, class, and perceptions of discrimination by the police. Crime \& Delinquency, 45(4), 494-507.

Weitzer, R., \& Tuch, S. A. (2002). Perceptions of racial profiling: Race, class, and personal experience. Criminology, 40(2), 435-456.

Western, B., Kling, J. R., \& Weiman, D. F. (2001). The Labor Market Consequences of Incarceration. Crime and Delinquency, 47(3), 410-427.

Whaley, A. L. (1992). A culturally sensitive approach to the prevention of interpersonal violence among urban Black youth. Journal of the National Medical Association, 84(7), 585-588.

White, M. (2014). Police Officer Body-Worn Cameras: Assessing the Evidence, Washington, DC: Office of Community Oriented Policing Services.

Wilkinson, D. L., Beaty, C. C., \& Lurry, R. M. (2009). Youth violence-crime or self-Help? Marginalized urban males' perspectives on the limited efficacy of the criminal justice system to stop youth violence. The ANNALS of the American Academy of Political and Social Science, 623(1), 25-38.

Williams, K. R. (1984). Economic sources of homicide: Reestimating the effects of poverty and inequality. American Sociological Review, 49(2), 283-289. 
Wilson, W. J. (1987). The Truly Disadvantaged: The Inner City. The Underclass, and Public Policy. Chicago, IL: University of Chicago Press.

Wilson, C. P., \& Wilson, S. A. (2014). Are We There Yet? Perceptive Roles of African American Police Officers in Small Agency Settings. Western Journal of Black Studies, 38(2) 123-133.

Wilson, C. P., Wilson, S. A., \& Gwann, M. (2016). Identifying barriers to diversity in law enforcement agencies. Journal of Ethnicity in Criminal Justice, 14(4), 231-253.

Wilson, C. P., Wilson, S. A., Luthar, H. K., \& Bridges, M. R. (2013). Recruiting for diversity in law enforcement: An evaluation of practices used by state and local agencies. Journal of Ethnicity in Criminal Justice, 11(4), 238-255.

Wilson, C. P., Wilson, S. A., \& Thou, M. (2015). Perceptions of African American police officers on racial profiling in small agencies. Journal of Black Studies, 46(5), 482-505.

Wilson, W. J., \& Aponte, R. (1985). Urban poverty. Annual Review of Sociology, 11(1), 231-258.

Wintemute, G. J. (2015). The epidemiology of firearm violence in the twenty-first century United States. Annual Review of Public Health, 36(2015), 5-19.

Xu, J. Q., Murphy, S. L., Kochanek, K. D., \& Bastian, B. A. (2016). Deaths: Final data for 2013 National vital statistics reports; vol 64 no 2. Hyattsville, MD: National Center for Health Statistics. 


\title{
APPENDICES
}

Cities Used for the Analysis

\author{
City, State \\ Conway, AR \\ Little Rock, AR \\ North Little Rock, AR \\ Gilbert, AZ \\ Aurora, CO \\ Westminster, CO \\ Centennial, $\mathrm{CO}$ \\ Boulder, CO \\ Longmont, $\mathrm{CO}$ \\ Lakewood, CO \\ Broomfield, $\mathrm{CO}$ \\ Denver, CO \\ Bristol, CT \\ Danbury, CT \\ East Hartford, CT \\ New Haven, CT \\ Norwalk, CT \\ Stamford, CT \\ Stratford, CT \\ West Hartford, CT \\ Wilmington, DE \\ Des Moines, IA \\ Cedar Rapids, IA \\ Davenport, IA \\ Boise, ID \\ Nampa, ID \\ Wichita, KS \\ Lexington-Fayette, $\mathrm{KY}$ \\ Fall River, MA \\ Taunton, MA \\ Haverhill, MA \\ Lynn, MA \\ Chicopee, MA \\ Springfield, MA \\ Cambridge, MA \\ Framingham, MA \\ Lowell, MA \\ Malden, MA \\ Somerville, MA
}

Population

$(63,816)$

$(197,357)$

$(66,075)$

$(229,972)$

$(345,803)$

$(127,359)$

$(110,945)$

$(106,114)$

$(103,166)$

$(89,919)$

$(147,214)$

$(59,471)$

$(649,495)$

$(60,568)$

$(83,684)$

$(51,252)$

$(130,660)$

$(87,776)$

$(126,456)$

$(51,384)$

$(63,268)$

$(71,525)$

$(207,510)$

$(128,429)$

$(102,157)$

$(214,237)$

$(86,518)$

$(386,552)$

$(308,428)$

$(88,697)$

$(56,069)$

$(62,088)$

$(91,589)$

$(55,717)$

$(153,703)$

$(107,289)$

$(68,318)$

$(108,861)$

$(60,509)$

$(78,804)$ 


$\begin{array}{ll}\text { Waltham, MA } & (62,227) \\ \text { Quincy, MA } & (93,494) \\ \text { Brockton, MA } & (94,089) \\ \text { Grand Rapids, MI } & (192,294) \\ \text { St. Clair Shores, MI } & (60,070) \\ \text { Sterling Heights, MI } & (131,224) \\ \text { Warren, MI } & (134,873) \\ \text { Farmington Hills, MI } & (81,295) \\ \text { Novi, MI } & (57,960) \\ \text { Royal Oak, MI } & (58,946) \\ \text { Southfield, MI } & (73,006) \\ \text { Troy, MI } & (82,821) \\ \text { Dearborn, MI } & (95,884) \\ \text { Dearborn Heights, MI } & (56,620) \\ \text { Detroit, MI } & (688,701) \\ \text { Livonia, MI } & (95,208) \\ \text { Taylor, MI } & (61,817) \\ \text { Westland, MI } & (82,578) \\ \text { Joplin, MO } & (50,789) \\ \text { Kansas City, MO } & (467,007) \\ \text { Fargo, ND } & (113,658) \\ \text { Manchester, NH } & (110,378) \\ \text { Nashua, NH } & (87,137) \\ \text { Hamilton, OH } & (62,258) \\ \text { Youngstown, OH } & (65,184) \\ \text { Cincinnati, OH } & (297,517) \\ \text { Cleveland, OH } & (390,113) \\ \text { Warwick, RI } & (81,971) \\ \text { Cranston, RI } & (80,566) \\ \text { Pawtucket, RI } & (71,172) \\ \text { Providence, RI } & (177,994) \\ \text { Charleston, SC } & (127,999) \\ \text { Mount Pleasant, SC } & (74,885) \\ \text { North Charleston, SC } & (104,054) \\ \text { Greenville, SC } & (61,397) \\ \text { Columbia, SC } & (133,358) \\ \text { Rock Hill, SC } & (69,103) \\ \text { Sioux Falls, SD } & (164,676) \\ \text { Chattanooga, TN } & (173,366) \\ \text { Jackson, TN } & (67,685) \\ \text { Knoxville, TN } & (183,270) \\ \text { Bartlett, TN } & (58,226) \\ \text { Memphis, TN } & (653,450) \\ \text { Pearland, TX } & (100,065) \\ \text { Frisco, TX } & (136,791) \\ & \end{array}$


Plano, TX

Rowlett, TX

Lewisville, TX

Fort Worth, TX

Georgetown, TX

Salt Lake City, UT

Sandy, UT

West Jordan, UT

Provo, UT

Ogden, UT

Richmond, VA

Alexandria, VA

Chesapeake, VA

Hampton, VA

Newport News, VA

Norfolk, VA

Portsmouth, VA

Roanoke, VA

Suffolk, VA

Virginia Beach, VA

Vancouver, WA

Bellevue, WA

Kent, WA

Kirkland, WA

Federal Way, WA

Tacoma, WA

Seattle, WA

Milwaukee, WI
$(274,409)$

$(58,043)$

$(101,074)$

$(792,727)$

$(54,898)$

$(191,180)$

$(90,231)$

$(110,077)$

$(116,288)$

$(84,249)$

$(214,114)$

$(148,892)$

$(230,571)$

$(136,699)$

$(182,020)$

$(246,139)$

$(96,205)$

$(98,465)$

$(85,728)$

$(448,479)$

$(167,405)$

$(133,992)$

$(124,435)$

$(84,430)$

$(92,734)$

$(203,446)$

$(652,405)$

$(599,164)$ 


\title{
List of Violent Crimes
}

\author{
Murder/Nonnegligent Manslaughter \\ Kidnapping/Abduction \\ Forcible Rape \\ Forcible Sodomy \\ Sexual assault with an Object \\ Forcible Fondling \\ Robbery \\ Aggravated Assault \\ Simple Assault \\ Extortion/Blackmail.
}


VITA

CANDICE D. AMMONS-BLANFORT

Miami, FL 33180

$\begin{array}{ll}\text { Fall } 2013 & \begin{array}{l}\text { B.S., Criminal Justice } \\ \text { University of Tennessee } \\ \text { Chattanooga, Tennessee }\end{array} \\ \text { Spring } 2015 & \begin{array}{l}\text { M.S., Criminal Justice } \\ \text { University of Tennessee } \\ \text { Chattanooga, Tennessee }\end{array} \\ \text { Summer 2019 } & \begin{array}{l}\text { Ph.D., International Crime and } \\ \text { Justice } \\ \text { Florida International University } \\ \text { Miami, Florida }\end{array} \\ & \begin{array}{l}\text { Online Instructor } \\ \text { Florida International University } \\ \text { Miami, Florida }\end{array} \\ & \begin{array}{l}\text { Adjunct Instructor } \\ \text { Florida International University } \\ \text { Miami, Florida }\end{array} \\ & \begin{array}{l}\text { Adjunct Professor } \\ \text { University of Tennessee } \\ \text { Chattanooga, Tennessee }\end{array}\end{array}$

Researched and Created Knox's Fire Investigator's Guide q (Training Manual)

Departmental Independent Study Thesis: The Oversexualization of Women in PrimeTime Crime Dramas

Departmental Independent Study Thesis: Police, Courts and Corrections in Hispaniola and America: A Cultural Relativism Perspective

Dissertation: Taking Matters into Your Own Hands: Self-Help and Black Firearm Crime

2011 HOPE Scholarship Recipient

2014 Criminal Justice Graduate Assistantship 
2015 International Crime and Justice Teaching Assistantship

2017 International Crime and Justice Digital

Assistantship

\section{PUBLICATIONS AND PRESENTATIONS}

Meldrum, R. C., Jackson, D. B., Archer, R., \& Ammons-Blanfort, C. D. (2018). Perceived School Safety, Perceived Neighborhood Safety, and Insufficient Sleep Among Adolescents. Sleep Health.

Garland, T. S., Blackburn, A. G., Browne, J. A., \& Blanfort, C. D. (2017). Prime-Time Representations of Female Federal Agents in Television Dramas. Feminist Criminology, 1557085117693089.

"The Moderating Effect of Low Self-Control on the Relationship between Violent Victimization and Delinquency: A Cross-National Test," presented at the annual meeting of the American Society of Criminology (Philadelphia, 2017)

"Women in Prime-Time: Representation of Federal Female Officers," presented at the annual meeting of the Academy of Criminal Justice Sciences (Orlando, 2015) 